\title{
VÝZNAM RELIKTŮ DOPRAVNÍHO POHYBU PŘI INTERPRETACI VELKOMORAVSKÉHO HRADIŠTĚ U BOJNÉ (OKRES TOPOLČANY)
}

\author{
DUŠAN CENDELÍN - PAVEL BOLINA
}

\begin{abstract}
Abstrakt: Již od počátku výzkumu pravěkých a raně středověkých hradišt'i středověkých hradi̊ můžeme sledovat snahy o uchopení jejich vztahu k dálkovým komunikacím. Návaznosti na dobovou komunikační sít' nepochybně mnoho vypovídají o přićinách výběru daného mista staviteli fortifikace a o jejím vztahu $k$ dalšim lokalitám, jsou však i nezastupitelným zdrojem informaci při vyhodnocováni poznatků z archeologického výzkumu. Přikladem lokality, u níž návazné trasy cest mohou ke zhodnocení významu hradiště hodně ríci, je i velkomoravská Bojná, skrytá v lesich Považského Inovce. Jak se vyvijí sama archeologie, mění se i metodika výzkumu starých komunikací, která u nás zejména po roce 2000 zaznamenala nebývalý rozvoj. Ukázala se predevšim nesprávnost již zažitých představ o vedeni starých dopravních tras údolími podél potoků a řek, ale i význam vyhledávání, dokumentace a vyhodnocování dochovaných reliktů dopravního pohybu. Může proto být zajímavé sledovat, zda a nakolik se posune interpretace dané lokality, pokud se při zkoumáni jejich komunikačních souvislosti vycházi nebo nevychází z onoho dnes již překonaného modelu s prevažujicím vedením starých cest údolimi podél vodotečí.
\end{abstract}

Klíčová slova: Bojná - Krajné - Považský Inovec - staré komunikace - úvozy.

\section{The Importance of Traffic Relics in the Interpretation of a Great Moravian Hillfort near Bojná (Topol'čany District)}

\begin{abstract}
Efforts to understand the relationship between prehistoric and early medieval hillforts and medieval castles and long-distance communications can be traced back to the outset of their research. Beyond doubt, connections with period communication networks provide important information about the reasons behind the selection of a particular site by the builders of a hillfort and about its relationship with further locations. At the same time, they present a major source of information when assessing findings from archaeological research. The Great Moravian hillfort of Bojná hidden in the forests of Považský Inovec, Slovakia is an example of a location where the routes of tracks can significantly contribute to the assessment of the hillfort's importance. As archaeology develops, so does the methodology of research into old communications, and in this country it has been among focal points of attention since 2000. The established hypotheses about communications leading through valleys along rivers and streams have been disproved, and the importance of searching for, documentation and assessment of the preserved relics of traffic has come to the fore. It will be interesting to observe if and how interpretations of locations change when, during the analysis of their communication relations, researchers employ the now obsolete model with old tracks predominantly running through valleys along watercourses, and when they don't.
\end{abstract}

Key words: Bojná - Krajné - Považský Inovec - old communications - farm tracks.

Jednou z hlavních tras, která v představách o nejstarší komunikační síti na Slovensku (poslední přehled literatury viz Pažinová-Beljak-Slámová-Beláček 2013, 154-156) vždy hrála důležitou roli, byla tzv. Česká cesta. Z vrcholně středověkého písemného pramene datovaného k 6. lednu 1336 se o ní ví, že vedla z Budína přes Ostřihom, Dvory nad Žitavou, Šintavu, Trnavu a Šaštín (CDM VII, 76-77 č. 102). Již Václav Chaloupecký (1923) předpokládal, že prostřednictvím České cesty měla s Moravou spojení i Nitra. Spojení Nitry s přechodem Váhu u Šintavy, vzpomínané roku 1268 jako „magna via, que de Nitria vadit ad Semtey“ (Šmilauer 1932, 80), ovšem spíše odráží situaci až ve vrcholném středověku, než by mohlo vypovídat o době velkomoravské. Štefan Janšák, jehož průzkum a dokumentace pozůstatků České cesty na přechodu Malých Karpat patř́i od přelomu 50. a 60. let 20. století k nezpochybnitelným milníkům výzkumu starých komunikací v celoevropském měřítku, pak pod vlivem archeologických výzkumů Josefa Poulíka z 50. let 20. století soudil, že v době velkomoravské měla Nitra po České cestě spojení s mikulčickým hradištěm (např. Janšák 1961, 87; zde viz obr. 1:2).

Jak hluboce se tato představa zakořenila, svědčí kupř. pokus R. Krajčoviče, jímž s podivnou zacházkou k Pieštanům měly do trasy mezi Nitrou a Mikulčicemi být zapojeny v 70. letech 


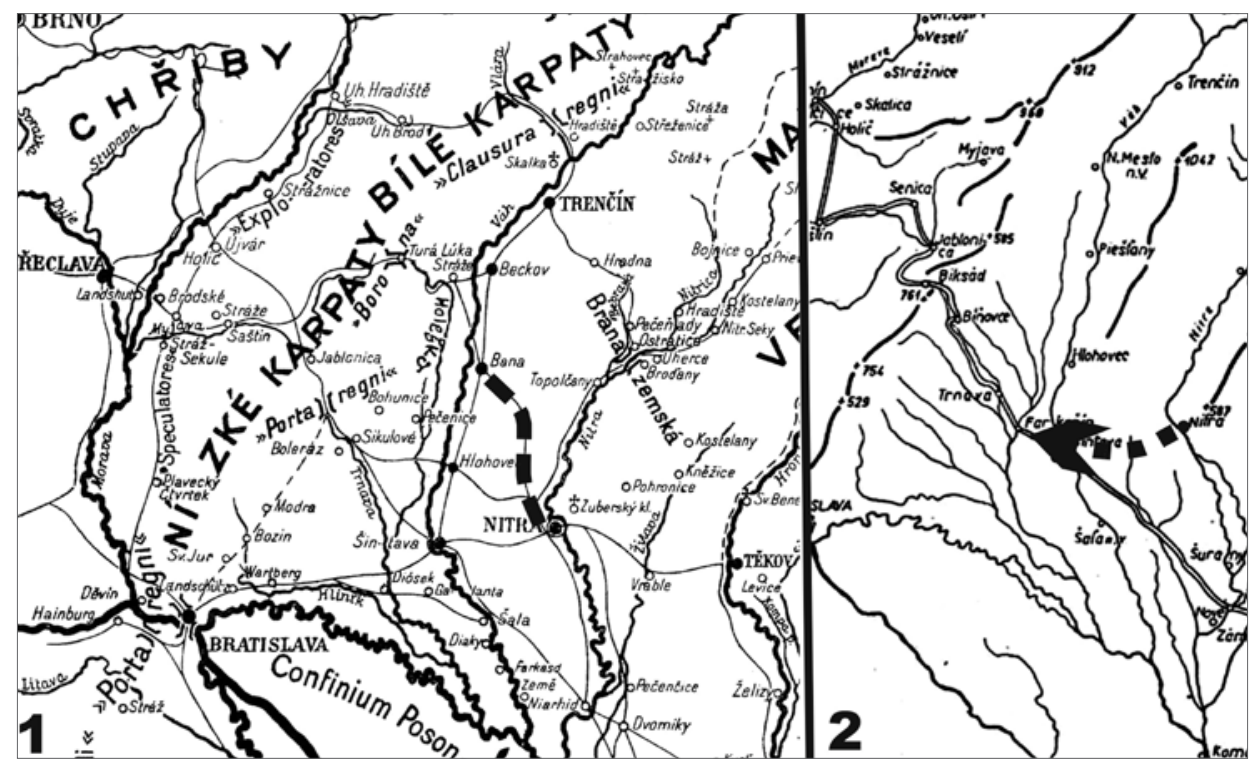

Obr. 1. Starší řešení historických pozemních komunikací na jihozápadním Slovensku v návaznosti na Nitru. 1 - podle V. Chaloupeckého (1923, Př́íloha 3) se zvýrazněním trasy přes Považský Inovec; 2 - podle Š. Janšáka (1961, 82) s přidáním šipky od Nitry k tzv. České cestě.

Abb. 1. Älterer angenommener Verlauf der historischen Landverkehrswege in der Südwestslowakei in Bezug zu Nitra. 1 - nach V. Chaloupecký (1923, Anhang 3) unter Hervorhebung der durch den Gebirgszug Považský Inovec führenden Trasse; 2 - nach Š. Janšák (1961, 82) unter Hinzufügung eines Pfeils von Nitra zur sog. Böhmischen Straße.

20. století zkoumané důležité velkomoravské lokality u Ducového a Pobedimi (Krajčovič 1992; k Pobedimi a Ducovému viz např. Bialeková 1978; 1998; Ruttkay 1975; 2005). To ovšem byl extrém, jinak až do konce 20. století se odborná literatura držela Janšákovy koncepce (např. Hanuliak 1998; Slivka 1998). Teprve významné objevy na velkomoravském hradisku u Bojné (okr. Topol'čany) v prvním decéniu nového tisíciletí umožnily K. Pietovi a A. Ruttkayovi vrátit se ke spojení Nitry s Povážím přes pohoří Považský Inovec (zde viz obr. 1:1) kdysi jen nadhozenému V. Chaloupeckým (1923, Př́loha 3). Uvedení autoři upřesnili toto spojení průběhem přes okolí Marhátu (kóta $748 \mathrm{~m}$ ) k důležitému vážskému brodu mezi Kostoliskem u Ducového a Pobedimí (Pieta-Ruttkay 2006, 55; Ruttkay 2006, 196). Konkrétní cíl této trasy, stejně jako před nimi V. Chaloupecký, přitom Pieta s Ruttkayem neřešili, posléze však bez bližšího upřesnění průběhu správně určili, že jde o trasu do Starého Města a Uherského Hradiště (např. Ruttkay 2012, 495).

Vstříc takovým závěrům zatím postupovaly poznatky z výzkumu reliktů starých komunikací na moravské straně Bílých Karpat (Cendelín 2010; 2011), zvláště zjištění více na sever probíhající staré trasy pravěkého základu, která z východní Moravy (ve středověku pod kontrolou hradů Lukov, Brumov a Vršatec) směřovala přes údolí Váhu u Ilavy do oblasti slovenských báňských měst (Bolina-Cendelín 2011; Cendelín-Bolina 2012). Ze zmíněného průzkumu přechodů Bílých Karpat vyplynulo, že pro př́stup na Nitransko ve směru od Uherského Hradiště byl nejvýhodnější přechod „Novolhotský“, ke kterému cesta sledovala přibližně linii Uherské Hradiště - Hluk - Blatnička - Suchov - Suchovské mlýny - Nová Lhota - pramen řeky Myjavy (obr. 2:1), přičemž poblíž hřebenu Bílých Karpat procházela předpolím pravěké fortifikace na výrazném vrchu Hradisko - kóta 636m (Cendelín 2010, 297, 313, pozn. 5; k hradišti z doby KLLP viz Dohnal 1984, 29; 1988, 39-40; Čižmář 2004, 135-136). O významu komunikace naznačeného průběhu a jejím používání hluboko do novověku svědčí její označení na II. vojenském mapování poblíž moravsko-slovenské hranice jako „Commerzialweg“. 


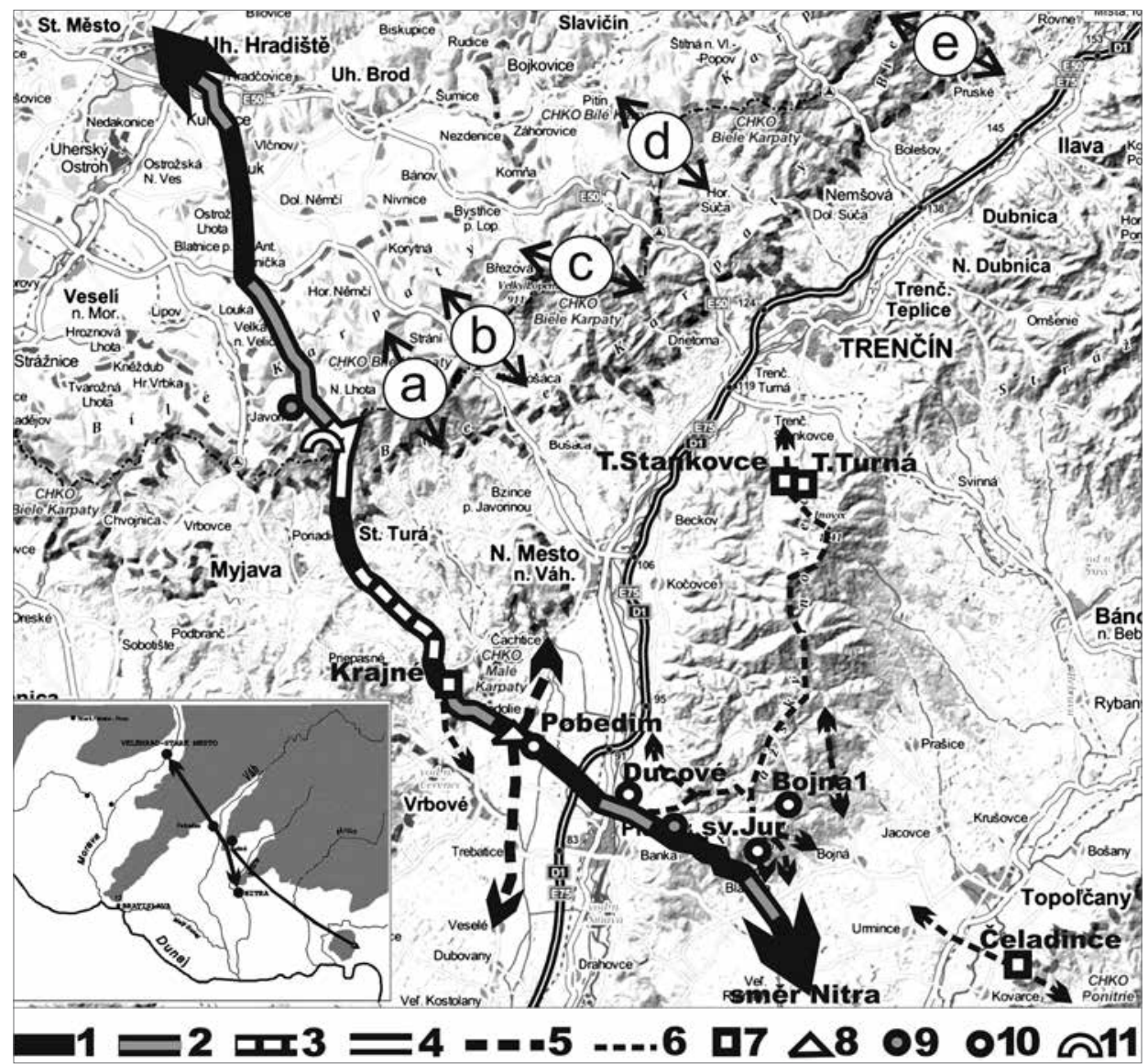

Obr. 2. Schéma historické trasy Uherské Hradiště-Nitra. 1 - hlavní průběh trasy; 2 - úseky doložené relikty trasy v terénu; 3 - úsek po dopravně výhodném návrší; 4 - úsek označený ve II. voj. mapování jako „Commerzialweg“; 5 - údolní trasa podél Váhu; 6 - další trasy ověřené relikty v terénu; 7 - lokality s relikty tras mimo jižní část Považského Inovce; 8 - mohyla z doby bronzové u Očkova; 9 - ke kontrole trasy v různých dobách vzniklé fortifikace u Javorníka (okr. Hodonín) a u Moravan n. V. (okr. Piešt’any); 10 - významná hradiště a dvorce z 9.-10. století při trase; 11 - polní šance na moravsko-slovenské hranici; a, b, c, d, e - přechody Bílých Karpat mimo trasu Uh. Hradiště-Nitra. Mapový podklad: http://www.mapy.cz/, cit. 15. 6. 2014.

Abb. 2. Schema der historischen Trasse Uherské Hradiště-Nitra. 1 - Hauptverlauf der Trasse; 2 - Abschnitte mit im Gelände belegten Trassenrelikten; 3 - Abschnitt durch verkehrsmäßig geeignete Anhöhe; 4 - in der II. militärischen Kartierung als „Commerzialweg“ bezeichneter Abschnitt; 5 - Taltrasse entlang der Waag; 6 - weitere im Gelände verifizierte Trassen; 7 - Fundstellen mit Trassenrelikten außerhalb des südlichen Teils des Gebirgszugs Považský Inovec; 8 - bronzezeitlicher Grabhügel bei Očkov; 9 - zur Kontrolle der Trasse in verschiedenen Zeiträumen entstandene Befestigungsanlagen bei Javorník (Bez. Hodonín) und bei Moravany a. d. Waag (Bez. Piešt'any); 10 - an der Trasse gelegene bedeutende Burgwälle und Herrenhöfe aus dem 9.-10. Jhdt.; 11 - Feldschanze an der mährisch-slowakischen Grenze; a, b, c, d, e - Übergänge durch die Weißen Karpaten außerhalb der Trasse Uherské Hradiště-Nitra. Kartenvorlage: http://www.mapy.cz/, aufgerufen am 15. 6. 2014.

Sestup na slovenskou stranu Bílých Karpat po hřbetu nad Starou Myjavou byl jednoznačně determinován přírodními podmínkami, pokračování od osady Poriadie (SV od Myjavy) po ideální suché trase, dodnes sledované silnicí na Krajné, rovněž nebylo těžké nalézt (obr. 3). ${ }^{1}$ U Krajného se překonávala první větší vodoteč na Slovensku, Jablonka, která se u jižního okraje

1 Při vyhledávání pozůstatků starých dopravních tras autoři vycházejí z již 15 let používané metodiky (např. Cendelín 1999; 2001; naposledy Bolina-Cendelín v tisku, 101-102), již lze s maximální stručností shrnout do tř́i pravidel: 1) pravidlo suché trasy, 2) pravidlo př́mého směru mezi danými výchozími body, 3) pravidlo minimální energetické náročnosti ve vzájemném ovlivnění s pravidly č. $1 \mathrm{a} 2$. Konkrétně to znamená, že mezi danými výchozími body (k tomu Bolina-Cendelín 2014, s tam uvedenou literaturou) se při respektování výše uvedených pravidel vyhledávají možná místa výskytu starých úvozů a jejich svazků, nebo jiných náznakủ zaniklého dopravního pohybu. Prvotním východiskem jsou archivní i aktuální mapové podklady různých měrítek, včetně těch nejpodrobnějších. Na základě získaných poznatků se vytipovávají konkrétní lokality s možným výskytem reliktů dopravního pohybu, které se následně ověrují v terénu. Terénní průzkum za účelem nalezení nebo vyloučení reliktů dopravního pohybu jako indikátorů dlouhodobého uživání trasy je nezbytnou součástí, která (stejně jako poznatky o významných archeologických lokalitách či informace písemných a dalších pramenů) tvoři v uvedené metodice zpětnou vazbu. 
obce spojuje s několika dalšími potoky. Sestup k Jablonce byl možný jednak po boku hřbetu $\mathrm{v}$ trase přibližně sledované dnešní silnicí do Krajného, jednak na samém konci hřbetu (WGS-84: N48 4145.0 E17 4133.0 ), ${ }^{2}$ kde se však v prudkém svahu v důsledku eroze nedochovaly relikty trasy v dostatečně čitelné podobě (obr. 4:3). Za jeden z původních bočních sestupů ze hřbetu lze pokládat hluboký suchý žleb přimykající se ke hřbitovu katolického kostela, dobře zobrazený na I. vojenském mapování (WGS-84: N48 4158.0 E17 41 19.0). Podobný žleb, zachycený na I. i II. vojenském mapování, se patrně nacházel na úpatí hřbetu na severním okraji osady těsně vedle současné silnice (WGS-84: N48 4231.0 E17 41 07.0; viz obr. 4:8, dnes je prostor zastavěn).

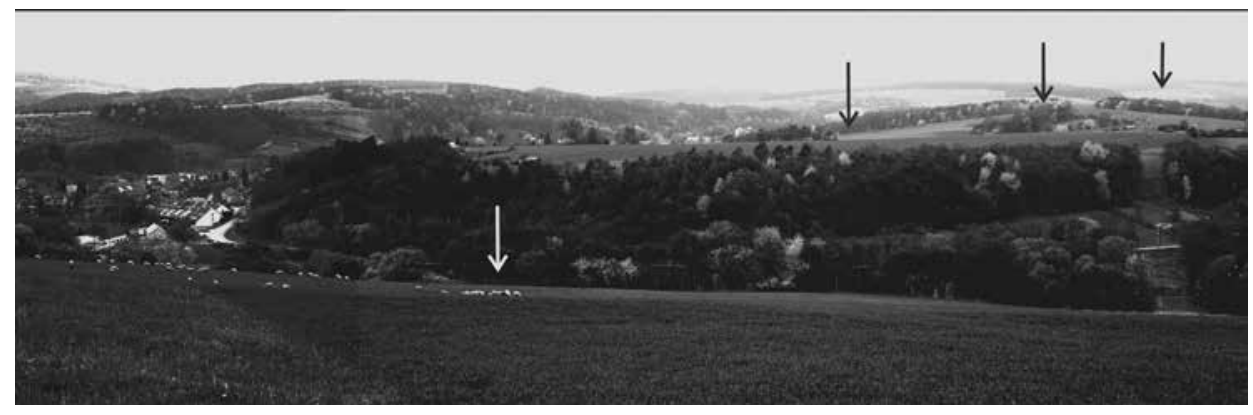

Obr. 3. Krajné, okr. Myjava. Pohled přes údolí Jablonky (bílá šipka) na jižní okraj obce a konec příhodného hřbetu, po kterém přicházela trasa z hřebene Bílých Karpat (černé šipky). Foto Pavel Bolina, Dušan Cendelín.

Abb. 3. Krajné, Bez. Myjava. Blick über das Jablonka-Tal (weißer Pfeil) am Gemeindesüdrand und Ende des geeigneten Bergrückens, über den die Trasse vom Bergkamm der Weißen Karpaten herführte (schwarze Pfeile). Foto Pavel Bolina, Dušan Cendelín.

Odpovídající brod přes potok Jablonku v Krajném lze předpokládat přibližně v místech dnešního mostu u bývalého zemědělského závodu. Původní situace potočních teras u tohoto brodu je po novodobých úpravách nejasná, ale zdejší přechod Jablonky dokládají dva relikty trasy na jejím pravém břehu (obr. 4:7). První (WGS-84: N48 4135.0 E17 41 29.0) má podobu opuštěného a postupně zaváženého úvozu cesty zachycené včetně tohoto úvozu na I. i II. vojenském mapování. Druhý relikt (WGS-84: N48 4130.0 E17 41 44.0) je tvořen soustavou mohutných úvozů za bezejmenným potůčkem, který poblíž brodu vtéká do Jablonky. Úvozy tohoto reliktu jsou nápadné svou velikostí (obr. 5), pro kterou byly zachycené již na I. vojenském mapování. Zda se však na jejich vzniku kromě trasy od Staré Myjavy podílela i jiná komunikace, např́íklad ta, o které V. Chaloupecký (1923, 81-82) předpokládal, že do Krajného přicházela od Šaštína (srov. obr. 1:1; obr. 4:4), je bez dalšího výzkumu těžké hodnotit. Po výstupu do sedla na hřebeni Malých Karpat mezi horou Drieňovicí $(453,9 \mathrm{~m})$ a Salaškami $(450,3 \mathrm{~m})$ by dokladem pokračování Chaloupeckého trasy na Trenčínsko teoreticky mohly být úvozy nad Častkovcemi (WGS-84: N48 41 20.4 E17 43 35.2), ty však lze spojovat i s těžební dopravní aktivitou nedaleké lokality Vápenky. ${ }^{3}$

Pro směr na Nitru jsou naproti tomu signifikantní úvozy na hřbetu vybíhajícím z hory Drieňovice nad osadou Obuchovci k jihovýchodu (WGS-84: N48 4019.9 E17 43 37.0). Tak jako $\mathrm{v}$ jiných případech obtížných úseků důležitých komunikací měla i trasa od přechodu Jablonky ještě jednu větev. Ta vycházela z výše uvedeného reliktu eliminujícího přechod bezejmenného potůčku a obcházela vrchol Drieňovice po jižní straně. Podle II. vojenského mapování sloužila v 19. století i jako trasa na Vrbové (obr. 4:2). Dobře identifikovatelným průběhem, zachyceným na II. i III. vojenském mapování, cesta po zmíněném hřbetu nad Obuchovcemi scházela v podobě dodnes zrretelného reliktu do údolí Váhu (obr. 6), kde těsně vedle místa jejího křížení s předpokládanou komunikací po pravobřežní vážské terase byla počátkem 60 . let 20. století zjištěna a archeologicky zkoumána velkolepá mohyla z mladší doby bronzové (Paulík 1962; 1962a; 1994).

2 Veškeré informace o pozicích jsou udávány dle GPS př́stroje Garmin GPSMAP 60CSX v souřadnicovém systému WGS-84.

3 Hodnocení výchozích bodů a průběhu Chaloupeckého trasy Šaštín - Krajné - Pováží spadá mimo rámec tohoto prríspěvku. 


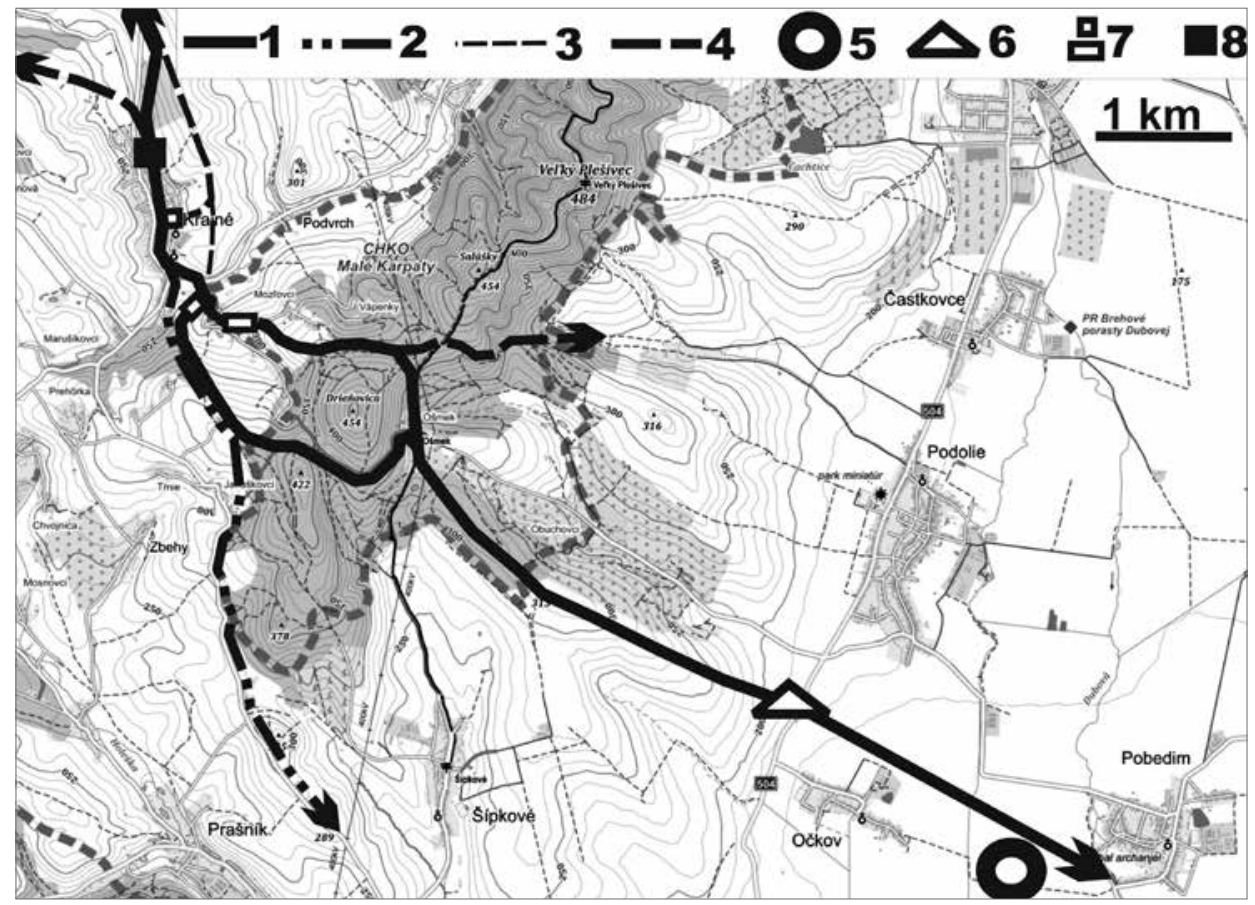

Obr. 4. Dopravní situace u Krajného (okr. Myjava). 1 - trasa Uherské Hradišťě-Nitra; 2 - spojka Krajné-Vrbové dle II. vojenského mapování; 3 - varianta linie trasy (1); 4 - možný průběh V. Chaloupeckým předpokládané trasy od Šaštína přes Krajné do Pováží; 5 - velkomoravské hradiště Pobedim; 6 - pravěká mohyla u Očkova; 7 - nejvýznamnějš́ dochované relikty dopravního pohybu na k. ú. Krajné; 8 - zástavbou obce zničený relikt, zachycený na I. a II. vojenském mapování. Mapový podklad: http://www.mapy.cz/, cit. 15. 6. 2014.

Abb. 4. Verkehrssituation bei Krajné (Bez. Myjava). 1 - Trasse Uherské Hradiště-Nitra; 2 - Anschlusstrasse Krajné-Vrbové gemäß der II. militärischen Kartierung; 3 - Variante der Trassenlinie (1); 4 - möglicher von V. Chaloupecký angenommener Trassenverlauf von Šaštín durch Krajné ins Waagtal; 5 - großmährischer Burgwall Pobedim; 6 - urzeitlicher Grabhügel bei Očkov; 7 - bedeutendste erhaltene Verkehrsbewegungsrelikte im Katastergebiet Krajné; 8 - durch Bebauung der Gemeinde zerstörtes Relikt, das von der I. und II. militärischen Kartierung erfasst wurde. Kartenvorlage: http://www.mapy.cz/, aufgerufen am 15. 6. 2014.

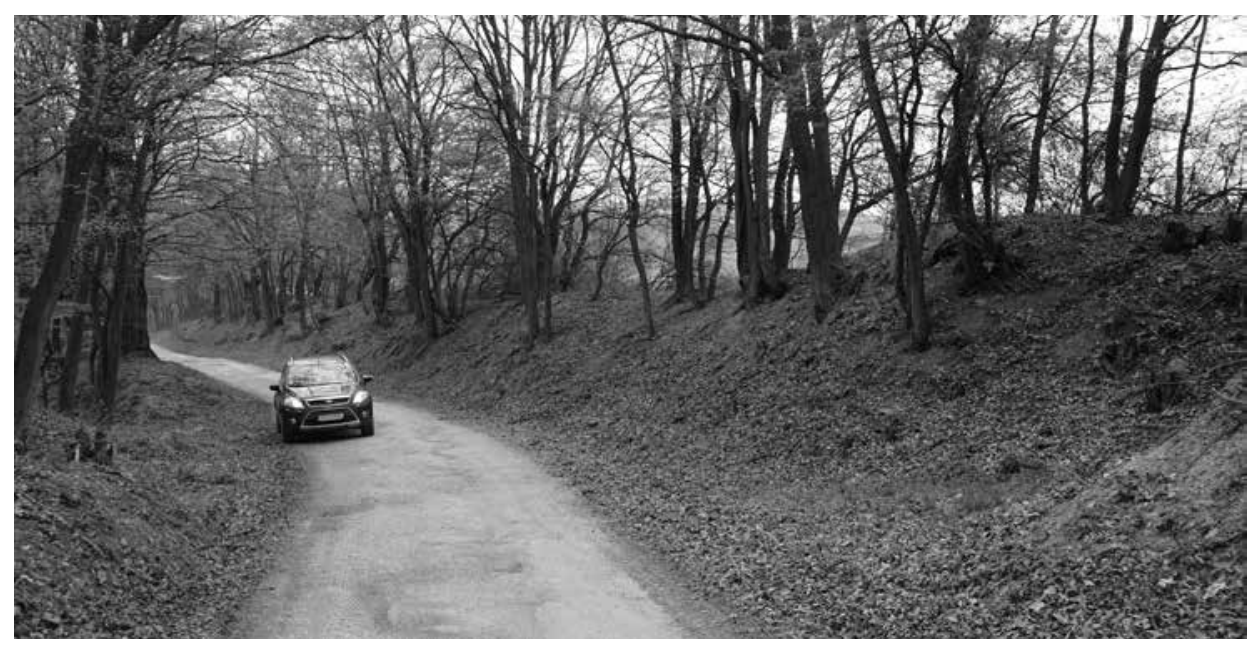

Obr. 5. Krajné, okr. Myjava. Jeden z mohutných úvozů trasy Uherské Hradiště-Nitra v místech výstupu severním svahem Malých Karpat, kde jej doposud využívá místní komunikace z Krajného (stav v dubnu 2014). Foto Pavel Bolina, Dušan Cendelín.

Abb. 5. Krajné, Bez. Myjava. Einer der mächtigen Hohlwege der Trasse Uherské Hradiště-Nitra an den Aufstiegsstellen über den Nordhang der Kleinen Karpaten, wo er bis heute von der aus Krajné führenden örtlichen Straße genutzt wird (Stand April 2014). Foto Pavel Bolina, Dušan Cendelín. 
V prodloužení dosavadního směru cesty od Krajného kolem mohyly do inundačního území údolí Váhu pak leží již zmíněné velkomoravské hradisko v Pobedimi (obr. 4:5, 6; Bialeková 1978; 1998). Z důvodu omezených možností výzkumu nebylo možno sledovat pokračování trasy přes údolí Váhu (ca 8 km), jde však jednoznačně o linii predikovanou A. Ruttkayem $(2012,495)$ k brodu, který byl na druhém břehu Váhu kontrolován fortifikací ve výrazné a dobře chráněné poloze Kostolec nad obcí Ducové (okr. Piešt’any). Přitom podle výsledků archeologického výzkumu A. Ruttkaye (napr. Ruttkay 1975; 2005) mohla výstavba valu a př́kopu na Kostolci být přibližně synchronní se vznikem zmíněné pravěké mohyly v Očkově. Pro dobu velkomoravskou je význam fortifikace nad brodem dobře zdůrazněn existencí rotundy, též zjištěné výzkumem A. Ruttkaye.

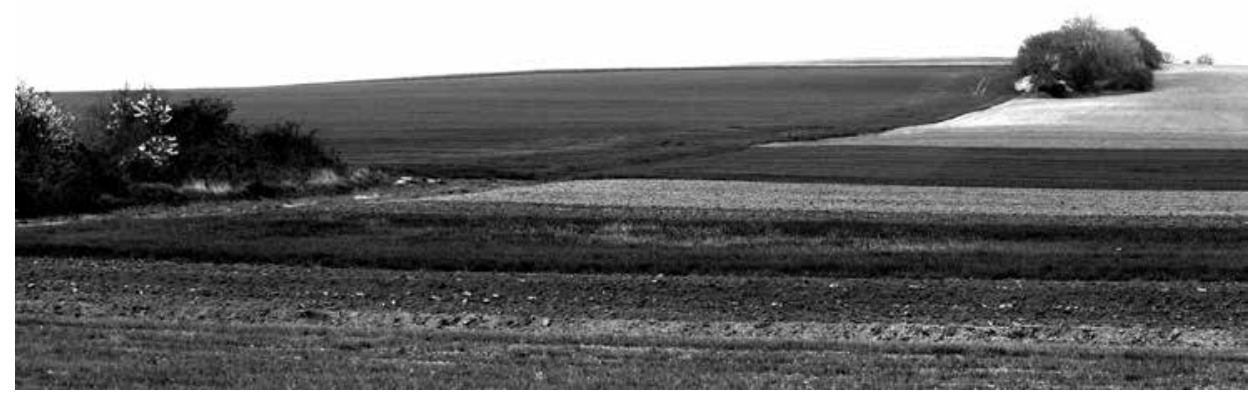

Obr. 6. Očkov, okr. N. Mesto n. Váhom. Pozủstatky staré cesty, která ve směru od Krajného scházela do údolí Váhu kolem mohyly z mladší doby bronzové (částečně v levé části snímku; stav v dubnu 2014). Foto Pavel Bolina, Dušan Cendelín.

Abb. 6. Očkov, Bez. Neustadt an der Waag. Überreste eines alten Weges, der aus Richtung Krajné ins Waagtal um die jungbronzezeitlichen Grabhügel hinabführte (teilweise im linken Bildteil; Stand April 2014). Foto Pavel Bolina, Dušan Cendelín.

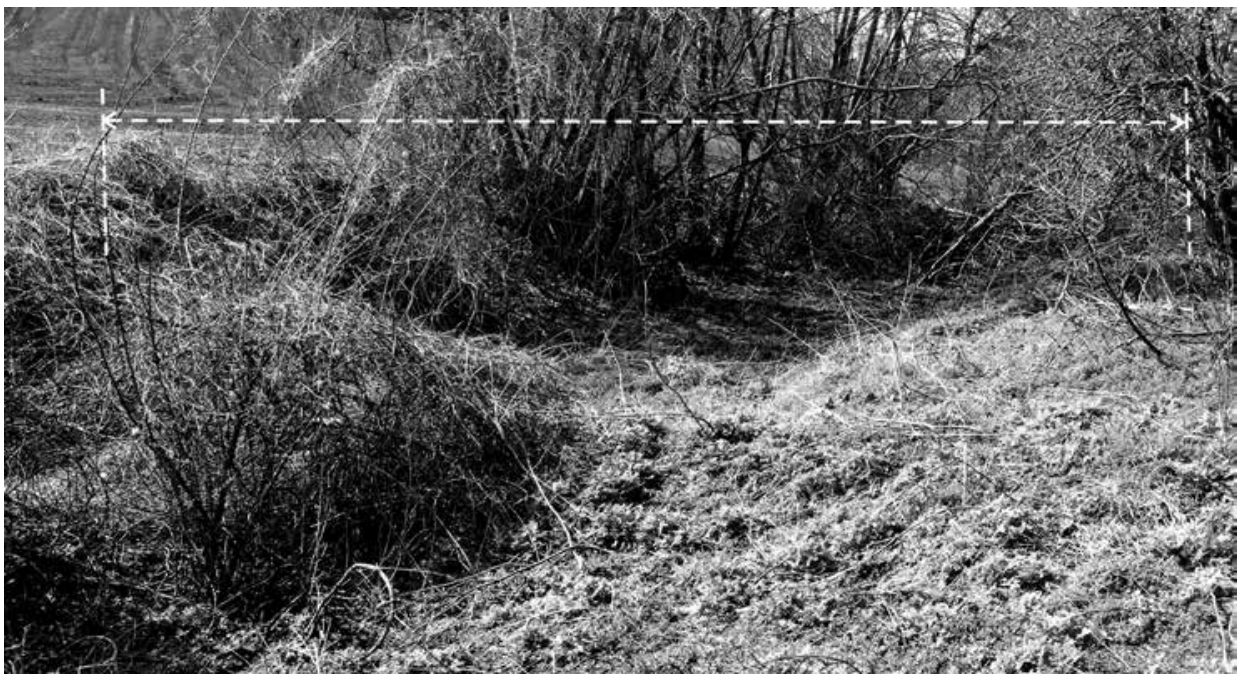

Obr. 7. Ducové, okr. Piešt’any. Opuštěný úvoz na výstupu od brodu přes Hubinský potok s vyznačením jeho šířky ca $10 \mathrm{~m}$ (relikt „a" na následujícím obrázku). Foto Pavel Bolina, Dušan Cendelín.

Abb. 7. Ducové, Bez. Piešt'any. Aufgegebener Hohlweg von der Furt durch den Bach Hubinský Potok mit eingezeichneter Breite von ca. $10 \mathrm{~m}$ (Relikt ,a“ in der nachfolgenden Abbildung). Foto Pavel Bolina, Dušan Cendelín.

Blízký přechod Váhu je dnes logicky mimo možnosti poznání povrchového průzkumu, ale zkoumaná trasa zanechala nezpochybnitelný relikt přímo pod skalou Kostolce. Zde u betonového můstku sestupuje k zaniklému brodu přes Hubinský potok široký, dnes postupně se zahliňující a vegetací zarůstající komunikační žleb (obr. 7, 8:a), jenž je pozůstatkem trasy, která po pře- 


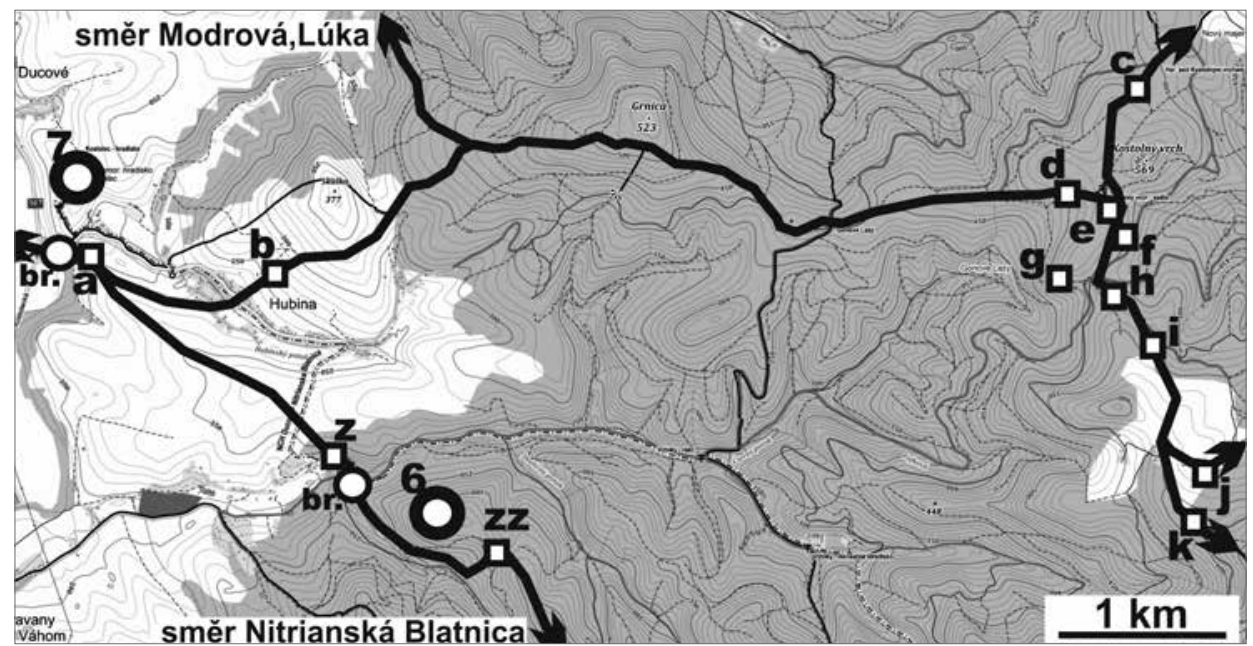

Obr. 8. Schéma dálkových tras na východ až jihovýchod od Ducového (číslování a další značení lokalit odpovídá celkové mapce obr. 14). 6 - Hradište u Moravan n. Váhom; 7 - Kostolec u Ducového; a-k, z-zz-místa reliktů dopravního pohybu. Mapový podklad: http://www.mapy.cz/, cit. 15. 6. 2014.

Abb. 8. Ferntrassenschema östlich bis südöstlich von Ducové (Nummerierung und weitere Kennzeichnung der Fundstellen entsprechen der Gesamtkarte von Abb. 14). 6 - Burgwall bei Moravany a.d. Waag; 7 - Burgwall Kostolec bei Ducové; a-k, z-zz-Stellen mit Verkehrsbewegungsrelikten. Kartenvorlage: http://www.mapy.cz/, aufgerufen am 15. 6. 2014.

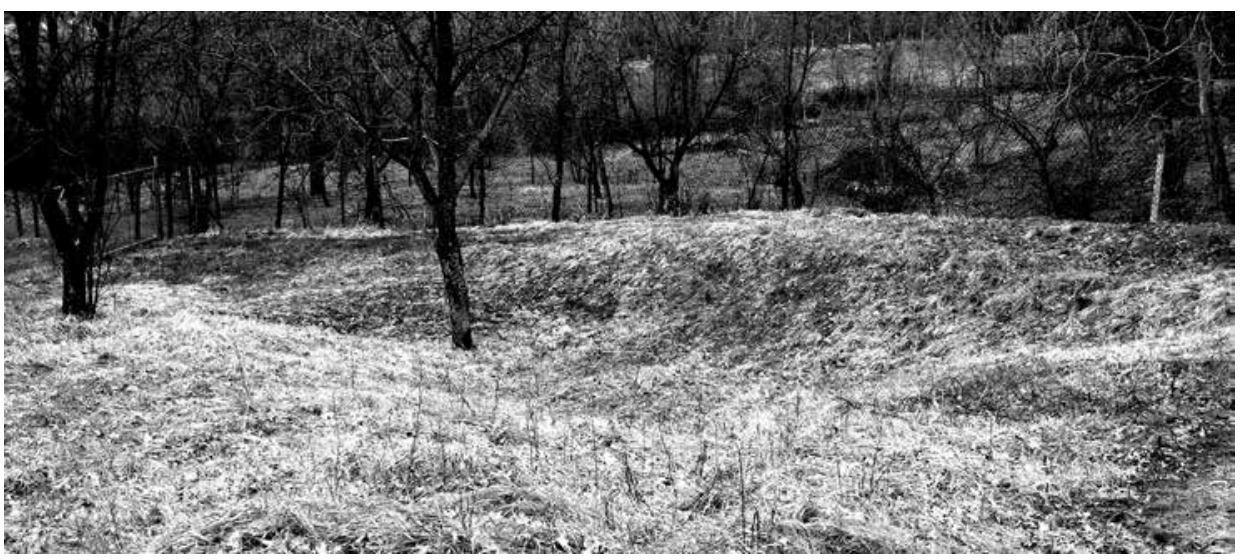

Obr. 9. Pokračování trasy od Ducového do Považského Inovce SV od Hubiny (srov. obr. 8:b). Foto Pavel Bolina, Dušan Cendelín. Abb. 9. Fortsetzung der Trasse von Ducové zum Gebirgszug Považské Inovec nordöstlich von Hubina (vgl. Abb. 8:b). Foto Pavel Bolina, Dušan Cendelín.

chodu Hubinského potoka směřovala $\mathrm{k}$ jihovýchodu na širokou pláň mezi Hubinským potokem a potokem Striebornica. Do Považského Inovce pokračovala dvěma větvemi. Relikty severnější lze dobře rozeznat severovýchodně od Hubiny (obr. 8:b, 9), relikty jižnější se nacházejí poblíž Hradište u Moravan nad Váhom (obr. 8:z-zz, 10; k původně snad pravěké fortifikaci s doloženým osídlením z 11.-12. století v poloze Hradište viz Ruttkay 1989, 73-75).

Dál pak náš průzkum trasy od Uherského Hradiště v mnohém mohl navázat na základní úvahu o jejím průběhu přes Považský Inovec, jak byla prezentována v úvodu zmíněnými pracemi K. Piety a A. Ruttkaye. Nutno předeslat, že jmenovaným autorům se podařilo ukázat složitost a mnohovrstevnost problematiky, od počátku však byla zřejmá slabina jejich řešení, spočívající v představě tras vedených dlouhými úseky v údolích podél potoků. Takové řešení je v rozporu s poznatky z jiných (námi i dalšími autory) zkoumaných historických komunikací dálkového významu ve srovnatelně členitém terénu (např. pro Šumavu srov. Kubů-Zavřel 2007-2009; ze 


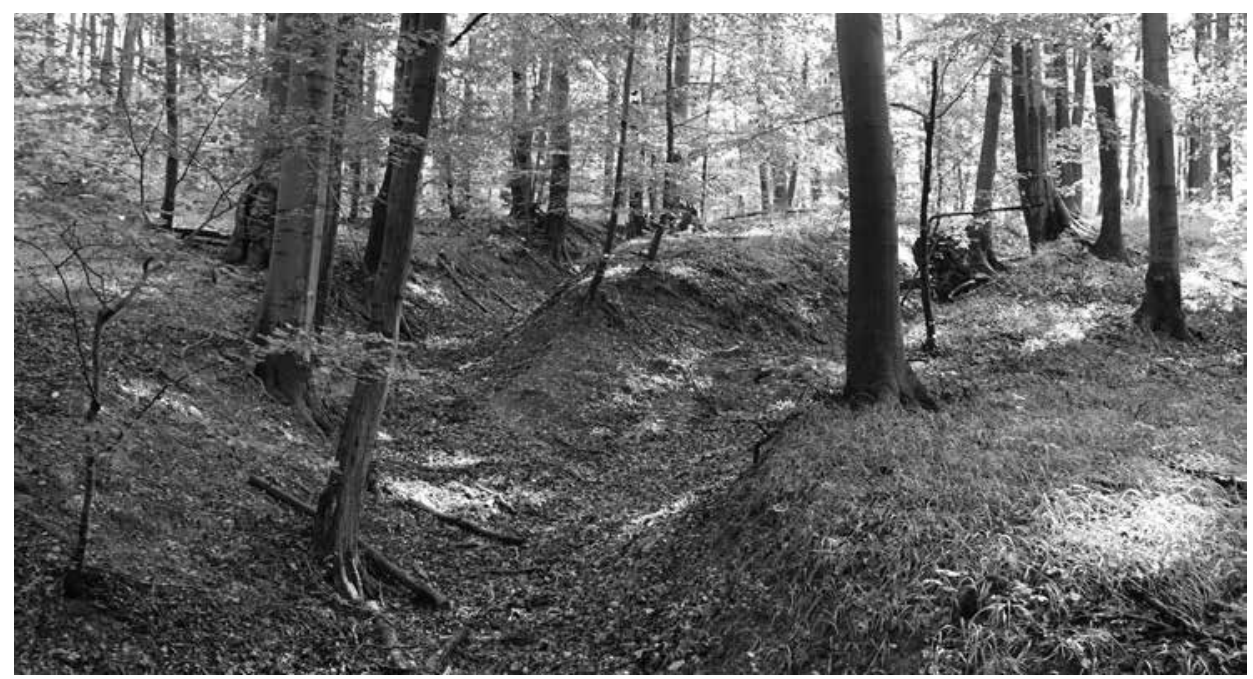

Obr. 10. Pokračování trasy od Ducového na výstupu svahem JV od Hradište u Moravan nad Váhom (srov. obr. 8:zz). Foto Pavel Bolina, Dušan Cendelín.

Abb. 10. Fortsetzung der Trasse von Ducové am Hangaufstieg südöstlich des Burgwalls bei Moravany a.d. Waag (vgl. Abb. 8:zz). Foto Pavel Bolina, Dušan Cendelín.

Slovenska nově Pažinová-Beljak-Slámová-Beláček 2013). Pokud staré komunikace ve středoevropských podmínkách někde bez vazby na osídlení do údolí vcházely, tak pouze proto, aby po př́hodné potoční terase dosáhly místa (např. rozdvojení údolí, výběžku s menším sklonem svahu apod.), kde nejdříve bylo možné přijatelným způsobem vystoupat na hřbet, do horského sedla či na náhorní rovinu. ${ }^{4}$

K. Pieta a A. Ruttkay správně určili, že jedna z větví trasy směřující z Nitranska na severozápad vcházela do prostoru Považského Inovce v nadmořské výšce $230 \mathrm{~m}$ údolím Bojnianky u Bojné (po vysoké levobřežní potoční terase - srov. text výše při pozn. 4). Předpokládali, že u paty výrazného hřbetu Žihlavníku (450-500 m n. m.), ve směru jihovýchod-severozápad oddělujícího Hradnou dolinu od údolí Bojnianky, se komunikace rozdělila a jednou větví postupovala k severoseverozápadu proti toku Bojnianky přímo pod pravěké hradiště Bojná II (o něm Pieta 2006, 173-179) a dál údolím na severozápad. Podle některých formulací K. Piety a A. Ruttkaye a jejich jen schematických náčrtů vedlo pokračování z údolí Bojnianky do východního svahu hlavního hřebene Inovce, který trasa překonávala bud' prudkým výstupem v poloze Nový Majer severně Kostolného vrchu (Pieta-Ruttkay 2006, Tab. F1), nebo v trase dnešní cesty z Nové Lehoty do Staré Lehoty (Ruttkay 2012, 488 - obr. 1, 497). Druhou větev vede K. Pieta částečně po hřebenu Žihlavníku, spolu s A. Ruttkayem i údolím Hradného potoka, ve kterém trasu větví do směru přes hradisko Bojná I na Ducové a do směru na Modrovou. V jejich podání se po průchodu areálem hradiště Bojná I hlavní převýšení směrem na dopravně významné návrší Jelenie Jamy překonávalo prudkým severovýchodním svahem Bieleného vrchu (kóta $732 \mathrm{~m}$ ). Severní větev pak měla podél Hradného potoka a jedné z jeho zdrojnic vystoupat na hlavní hřeben Inovce jižně od Kostolného vrchu (Pieta-Ruttkay 2006, 23).

Malou pravděpodobnost takto vedených tras, danou nejen nutností zdolávání velmi prudkých svahů kolmo na vrstevnice, ale i dlouhými úseky v potočních nivách, ${ }^{5}$ neprrímo při povr-

\footnotetext{
4 Tak např. původní trasa od Kostolce u Ducového na Nitru po překonání potoka Striebornica vcházela pod vrcholem Hradište do prríčného údolí bezejmenného potoka a po jeho pravobřežní terase pokračovala asi $600 \mathrm{~m}$ na jihovýchod, kde pozvolnějším svahem mohla prakticky kolmo na vrstevnice vystoupat do sedla mezi uvedenou fortifikací a navazujícím hřbetem (viz obr. 8:zz, 10). Jako hřebenová pak pokračovala dál k sedlu Gajda. Cesta zakreslená na II. vojenském mapování, která po přechodu Striebornice začíná mnohem dřive stoupat šikmo jižním svahem Hradište, je evidentně novověkého původu.

5 Například ve vlhčím období byla prakticky neprůchodná část údolí Bojnianky mezi patou Žihlavníku a hradištěm Bojná II. Původ současné cesty, zaříznuté do úpatí př́ikrého svahu Mladého háje, můžeme s velkou pravděpodobností klást až do novověku.
} 
chovém průzkumu potvrdila absence reliktů starých tras v kritických místech stoupání, kde by se charakteristické pozůstatky úvozů mohly vyskytovat. To je markantní zvláště u dálkové komunikace, u níž K. Pieta a A. Ruttkay předpokládali, že procházela přes hradiště Bojná I. Velmi dobře lze přitom rozeznat systém několika úvozů původní, z Hradné doliny stoupající př́istupové cesty do hradiště k severovýchodní bráně, zatímco její pokračování od jihozápadní brány směrem do svahu Bieleného vrchu je z hlediska výskytu reliktů dopravního pohybu nejen zcela sterilní, ale zdejší cesta je nevýrazná i ve srovnání s okolními běžnými lesními cestami (obr. 11).

Rozdíl v intenzitě pohybu přes obě brány je patrný i v samém prostoru hradiště. Od severovýchodní brány pokračuje postupně se zmenšující úvoz k nejvyššímu bodu hradiště, kde zaniká, dál k jihozápadní bráně pak cesta prakticky žádný úvoz nevytvořila. Představu dálkové obchodní trasy, jež by procházela hradiskem Bojná I (např. Ruttkay 2012, 499), nelze opírat ani o existenci jihozápadní brány, důležité z hlediska bezpečnosti hradiště, př́ístupu k nejbližšímu vodnímu zdroji, zásobování dřevem i možnosti kontrolovat cestu probíhající výše po úbočí Bieleného vrchu, která podle dochovaných reliktů (obr. 12:j, 1, m, n, y) z polohy Jelenie Jamy směřovala přibližně $\mathrm{k}$ jihu, dolů $\mathrm{z}$ Považského Inovce po dopravně př́ihodných hřbetech nad Lipovníkem a Bojnou.

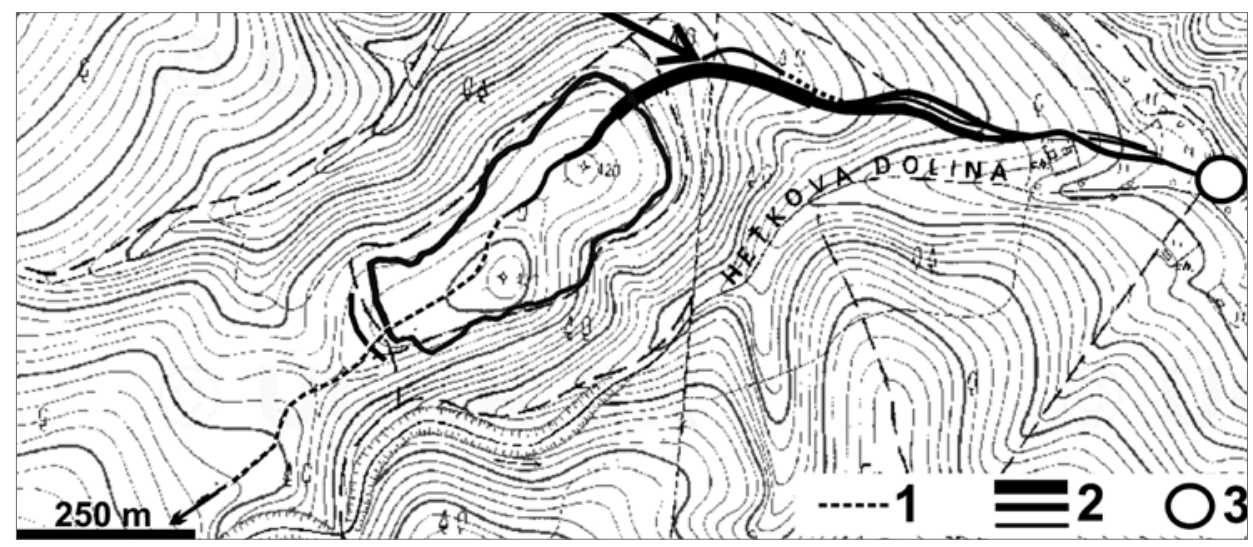

Obr. 11. Kontrast mezi relikty dopravního pohybu na přístupu k hradišti Bojná I z údolí Hradného potoka a cestou pokračující od jihozápadní brány výstupem do svahu Bieleného vrchu. 1 - úsek cesty přes hradiště (bez úvozu); 2 - současná úvozová cesta k hradišti a soustava opuštěných úvozů u severovýchodní brány (šipka v místě s rozdílem výšky dna současné cesty a opuštěného úvozu asi 1,2 m); 3 - brodové místo cesty $k$ hradišti v Hradné dolině. Mapový podklad: TM 10 (M-33-132-B-b-4_34-121-A-a-3), Ústredná správa geodézie a kartografie 1964, http://archivnimapy.cuzk.cz/topos52/010k/M_33_132_B_b_4_index.html, cit. 15.6.2014.

Abb. 11. Kontrast zwischen den Verkehrsbewegungsrelikten am Zugang zum Burgwall Bojná I vom Tal des Baches Hradná aus und dem Weg, der vom Südwest-Tor über den Hangaufstieg des Bergs Bielý Vrch weiterverläuft. 1 - Wegabschnitt durch den Burgwall (ohne Hohlweg); 2 - gegenwärtiger zum Burgwall führender Hohlweg und System aufgegebener Hohlwege am Nordost-Tor (der Pfeil befindet sich an einer Stelle, an welcher der Höhenunterschied zwischen heutigem und aufgegebenem Hohlweg ungefähr $1,2 \mathrm{~m}$ beträgt); 3 - Furt des Weges zum Burgwall im Hradná-Tal. Kartenvorlage: TM 10 (M-33-132-B-b-4_34-121-A-a-3), Zentralverwaltung Geodäsie und Kartographie 1964, http://archivnimapy.cuzk.cz/topos52/010k/M_33_132_B_b_4_index.html, aufgerufen am 15. 6. 2014.

Problematickou se v této souvislosti stává představa hradiska Bojná I jako střediska obchodu 9. století na významné dálkové komunikaci. Těžko též akceptovat, že pomístní název „Trhovisko“, zachycený Urbárnou mapou Bojné z konce 19. století ve svahu (!) nedaleko jihozápadní brány, by mohl být odrazem konání trhů na hradišti či v sedle před ním v době velkomoravské (Pieta-Ruttkay 2006, 25; Ruttkay 2012, 499). Pomístní názvy se základem „trh-“ jsou navíc relativně běžné. ${ }^{6}$ Nápadná je poloha těchto pomístních jmen mimo centra osad. Zda však se zde obchodovalo s dobytkem ve smyslu původní představy P. Ratkoše $(1978,252){ }^{7}$ lze pochybovat,

6 Toponymum Trhovisko, Trhovište a Trhovec se na Slovensku vyskytuje např. na katastrálních územích Dunajská Streda, Kežmarok, Krajné, Královský Chlmec, Križovany, Spišské Podhradie, nehledě na názvy obcí se základem „trh-“, např. Trhovište (okr. Michalovce), Horné a Dolné Trhovište (okr. Hlohovec).

7 Podle P. Ratkoše měla v raném středověku „Trhovište“ sloužit k zahánění a pozdějšímu prodeji zajatého bezprizorního dobytka, otroků a nevolníků. Na tuto hypotézu v souvislosti s „Trhovištem“ u Bojné též odkazuje A. Ruttkay (1989, 75). 


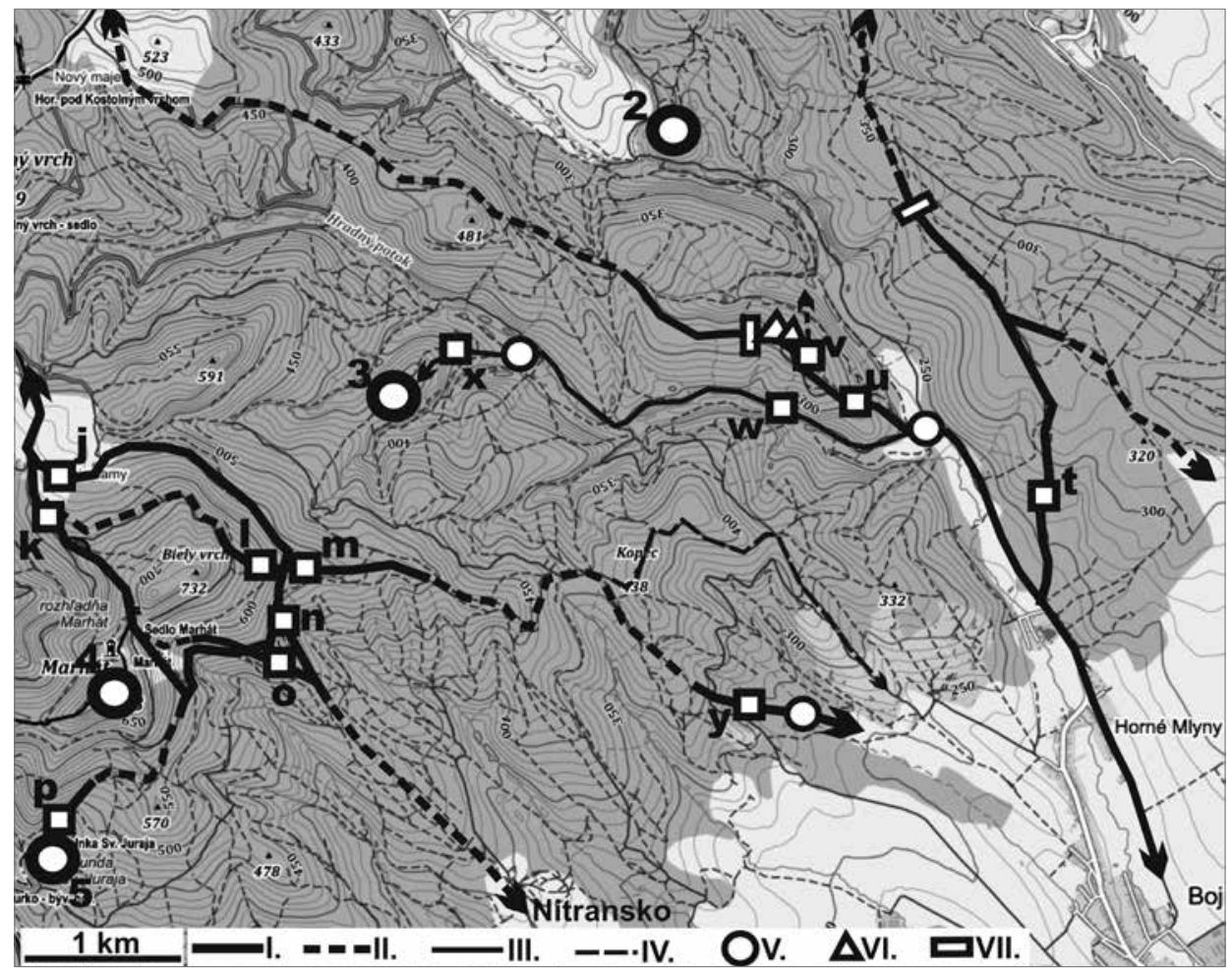

Obr. 12. Situace dálkových tras severozápadně od Bojné (číslování a další značení lokalit odpovídá celkové mapce obr. 14). 2 - pravěké hradiště Bojná II; 3 - hradiště Bojná I; 4 - pravěké hradiště Marhát; 5 - raně středověké osídlení u rotundy sv. Juraje; I. - trasy ověřené relikty; II. - předpokládané průběhy tras zatím blíže nezkoumané; III. - přístupová komunikace k velkomoravskému hradišti Bojná I; IV. - alternativa k předpokládanému pokračování dálkové trasy k osadě Bojná; V. - brodová místa; VI. - mohyly; VII. - lineární fortifikace přehrazující horské hřebeny v polohách Žihlavník a Mladý háj (tzv. Bojná III a Bojná IV); j-p,t-y - relikty dopravního pohybu (soupis s bližšími údaji viz Př́loha). Mapový podklad: http://www.mapy.cz/, cit. 15. 6. 2014.

Abb. 12. Lage der Ferntrassen nordwestlich von Bojná (Nummerierung und weitere Kennzeichnung der Fundstellen entsprechen der Gesamtkarte von Abb. 14). 2 - urzeitlicher Burgwall Bojná II; 3 - Burgwall Bojná I; 4 - urzeitlicher Burgwall Marhát; 5 - frühmittelalterliche Besiedelung an der St. Georg-Rotunde; I. - durch Relikte verifizierte Trassen; II. - bislang nicht näher untersuchte mutmaßliche Trassenverläufe; III. - Zugangsverkehrsweg zum großmährischen Burgwall Bojná I; IV. - Alternative zur angenommenen Fortsetzung der Ferntrasse zur Siedlung Bojná; V. - Furtstellen; VI. - Grabhügel; VII. - lineare Befestigungsanlagen, mit denen die Bergkämme in den Lagen Žihlavník und Mladý Háj gesperrt wurden (sog. Bojná III und Bojná IV); j-p,t-y - Verkehrsbewegungsrelikte (Verzeichnis mit näheren Angaben siehe Anhang). Kartenvorlage: http://www.mapy.cz/, aufgerufen am 15. 6. 2014.

nebot' jeho hypotéza vůbec nepočítala s možným vztahem takových topik k pojmenování některých cest. To by mohl být i případ Trhoviska u Bojné, vysvětlitelný patrně pozdějším využitím některé ze starých komunikací v okolí Bieleného vrchu jako dobytčí trasy. Jednu dobytčí trasu snad naznačuje i pomístní název Trhovica zhruba $3 \mathrm{~km}$ jihozápadně od Jeleních jam (k dalším podobným názvům v okolí viz obr. 14), které zmiňují jak P. Ratkoš $(1978,252)$, tak A. Ruttkay $(1989,75)$. Název lze interpretovat jako cestu na trh či z trhu, v českých zemích je topikum vícekrát doloženo jako Trhovice, nebo některou z jeho modifikací. ${ }^{8}$ Umístění Trhoviska u Bojné I (do svahu) také nemusí přesně odpovídat poloze, ke které se vztahovalo. Při známé tendenci k posunům a deformacím názvů na mapách mohla být určující lokalita toho názvu dosti vzdálená a na konci 19. století mohli zachytit pojmenování již jen části lesa, ke kterému se vztahovalo.

Ostatně posunem topika „Kamenne vráta“, na novodobých mapách nesprávně položeného do západní části Hradné doliny, vznikla i mylná představa, že tímto údolím procházela po celé jeho délce dávná komunikace, která jižně Kostolného vrchu vycházela na hlavní hřeben Inovce (Ruttkay 2012, 499; 505). Ze starších map, konkrétně z II. a III. vojenského mapování je však

8 Např́iklad pomístní název Trhovisko při okraji Valašských Klobouk, Trhovice u Zbraslavi aj. (Sedláček 1924; Cendelín 1999a, 48). 
zřejmé, že jako „Kamenne vráta“ se označovala poloha při kótě $568 \mathrm{~m}$ na hřebeni Inovce jižně Kostolného vrchu (zde viz obr. 13). Sám název „Kamenne vráta“ se bezpochyby původně vztahoval ke krátkému do skály zasekanému úseku hřebenové cesty (obr. 13), která (poté, co minula Kostolný vrch) se v daném místě vyhýbala pozoruhodné asi o deset metrů vyvýšené plošině 400 $\times 100 \mathrm{~m}$. Ze severu i od jihu měla plošina samostatné vstupy (obr. 13:e, g), po její východní straně pod dnešní cestou se mezi dvěma úvozy dochovaly zbytky zatím blíže nezkoumaného objektu, jehož účel mohl souviset s vybíráním mýta na cestě (obr. 13:f). Toponymum „Kamenne vráta“ známe i z jiných regionů Slovenska, zpravidla v souvislosti s významnou dálkovou trasou (severně od Smolenic na tzv. České cestě, severovýchodně Trebichavy na spojnici horního Ponitří s Rajeckou kotlinou, jihozápadně od Turé Lúky).

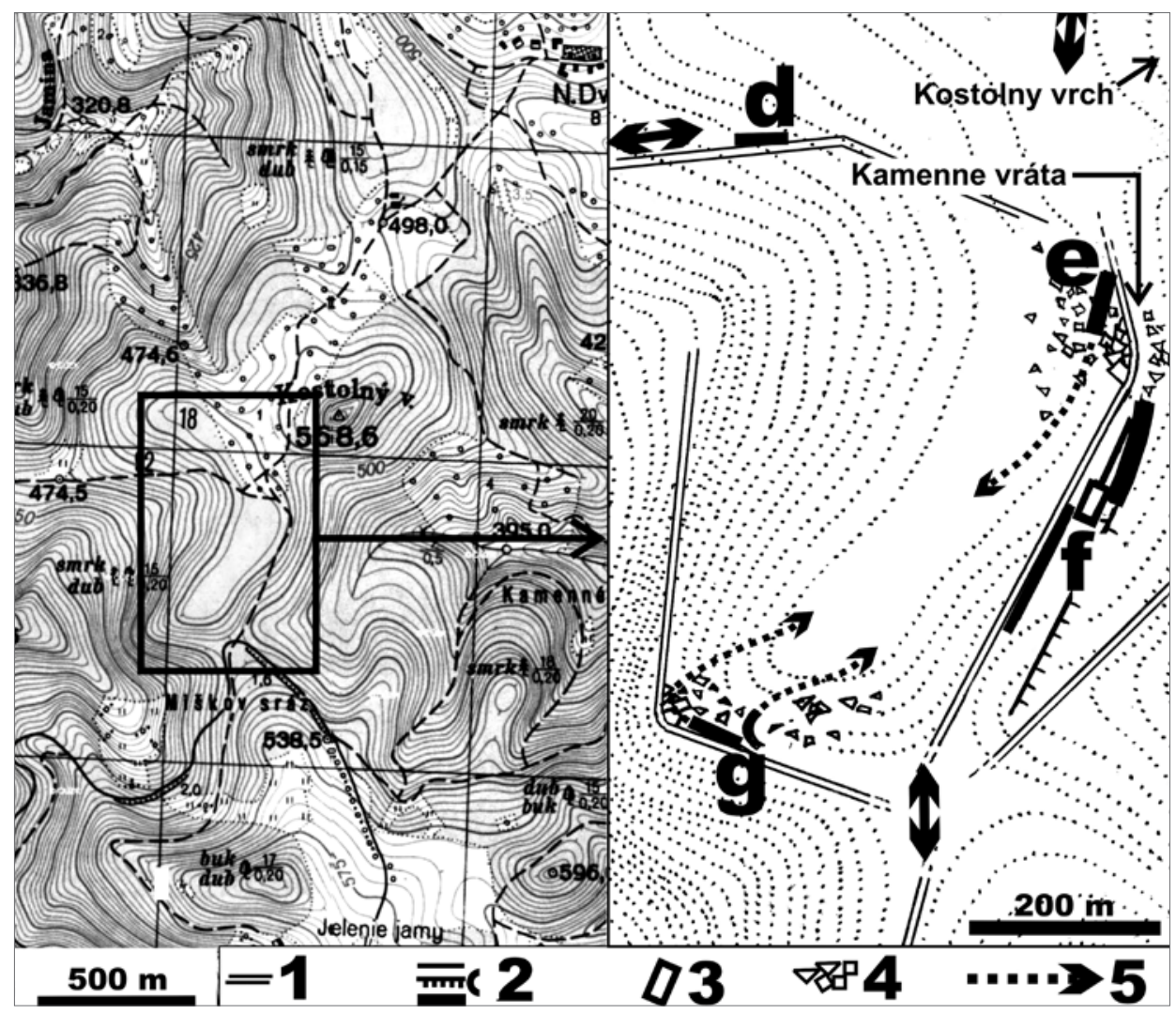

Obr. 13. Lokalita Kamenne vráta na hřebeni Považského Inovce. 1 - lesní cesty; 2 - relikty dopravního pohybu (značení odpovídá celkové mapce obr. 14); 3 - plošina po zaniklém objektu; 4 - skalní výstupy a skupiny balvanủ; 5 -předpokládané pokračování reliktů cestami na plošinu návrší; d-g - relikty dopravního pohybu (soupis s bližšími údaji viz Př́iloha); dvojité šipky - průběh dálkových tras sedlem Kamenne vráta. Mapový podklad: TM 25 (M-33-132-B-b), Generální štáb československé lidové armády 1955, http:// archivnimapy.cuzk.cz/topos52/025k/M_33_132_B_b_index.html, cit. 15.6.2014.

Abb. 13. Fundstelle Kamenne Vráta auf dem Bergkamm des Gebirgszugs Považský Inovec. 1 - Waldwege; 2 - Verkehrsbewegungsrelikte (die Kennzeichnung entspricht der Gesamtkarte von Abb. 14); 3 - Fläche eines wüsten Objektes; 4 - Felsvorsprünge und Ansammlung von Felsblöcken; 5 - mutmaßliche Fortsetzung der Relikte auf den Wegen zum Höhenplateau; d-g - Verkehrsbewegungsrelikte (Verzeichnis mit näheren Angaben siehe Anhang); Doppelpfeile - Ferntrassenverlauf über den Bergsattel Kamenne vráta. Kartenvorlage: TM 25 (M-33-132-B-b), Generalstab der tschechoslowakischen Volksarmee 1955, http://archivnimapy.cuzk. cz/topos52/025k/M_33_132_B_b_index.html, aufgerufen am 15.6.2014.

Skutečnost, že v pracích K. Piety a A. Ruttkaye nejsou trasy přes Považský Inovec vedeny v souladu se současnými poznatky o průběhu starých komunikací, by nemusela být považována za až tak vážný nedostatek, nebot' namísto údolím mnohde př́islušná komunikace vedla po paralelně probíhajícím táhlém horském hřbetu. Nedocenění hřbetních tras však vedlo k tomu, že ne 
ve všech př́ipadech byly správně uchopeny relikty dopravního pohybu ve výšinných polohách. ${ }^{9}$ V kombinaci s lineárními fortifikacemi, které v zatím blíže neurčené době dopravní koridory hřebenových tras příčně přetnuly za účelem snazší kontroly provozu na př́slušné komunikaci (viz obr. 12:VII), ${ }^{10}$ pak úvozy K. Pieta interpretoval jako součást opevnění neexistujících hradišt' Bojná III na horském hřbetu Žihlavník a Bojná IV na hřbetu Mladý háj nad levým břehem potoka Bojnianky. ${ }^{11}$ Dostatečně též nebyl zhodnocen vztah archeologicky zkoumaných mohyl na hřbetu Žihlavníku (srov. Pieta 2006, 179-185) k trase, která kolem nich prochází v podobě nejvýraznějšího systému úvozů v oblasti. ${ }^{12}$

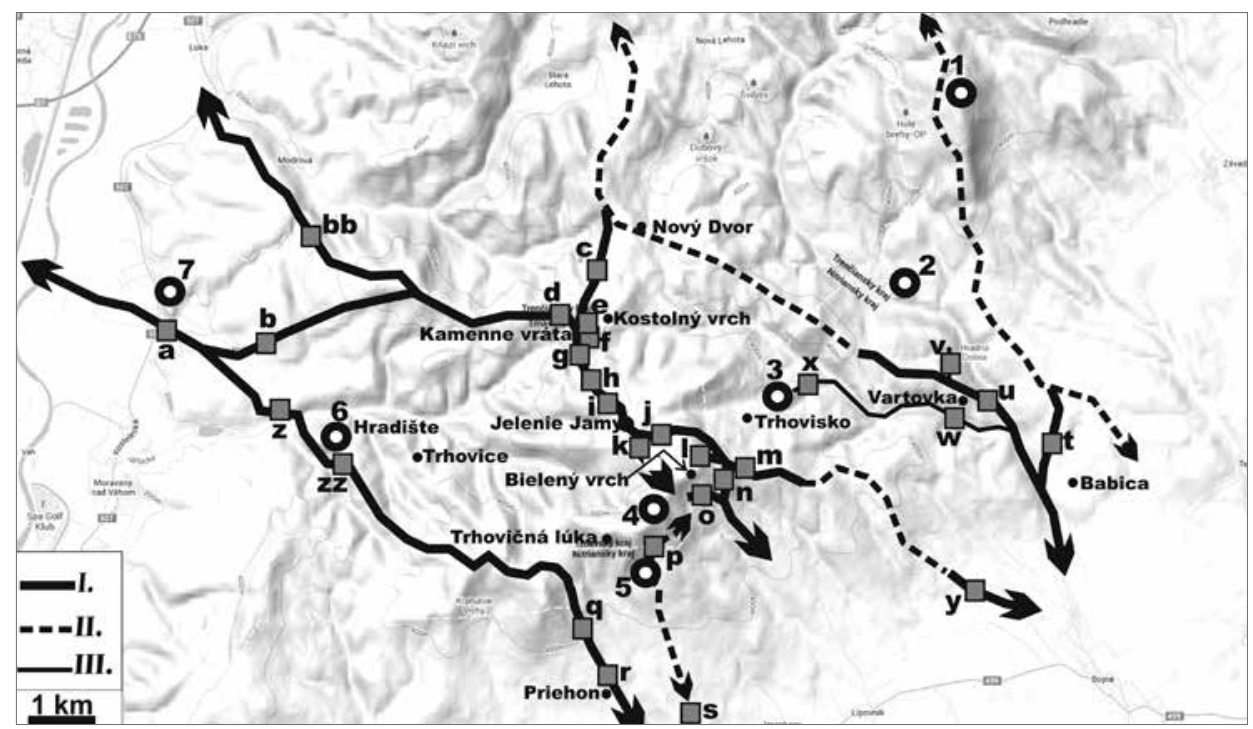

Obr. 14. Hlavní přechody Považského Inovce s vyznačením zjištěných pozůstatků starých cest a některých pomístních jmen. 1 - pravěké hradiště Úhrad; 2 - pravěké hradiště Bojná II; 3 - hradiště Bojná I; 4 - pravěké hradiště Marhát; 5 - raně středověké osídlení u rotundy sv. Juraje (polohy Púst' a Jurko); 6 - Hradište u Moravan; 7 - Kostolec u Ducového; I. - trasy ověřené relikty; II. - předpokládané průběhy tras zatím blíže nezkoumaných; III. - př́istupová komunikace k velkomoravskému hradisku Bojná I; a-zz-relikty dopravního pohybu (soupis s bližšími údaji viz Př́loha). Mapový podklad: http://www.google.com/maps/, cit. 15.6 .2014$.

Abb. 14. Hauptübergänge des Gebirgszugs Považský Inovec mit Kennzeichnung der entdeckten Überreste alter Wege und einigen Ortsbezeichnungen. 1 - urzeitlicher Burgwall Úhrad; 2 - urzeitlicher Burgwall Bojná II; 3 - Burgwall Bojná I; 4 - urzeitlicher Burgwall Marhát; 5 - frühmittelalterliche Besiedelung an der St. Georg-Rotunde (Lagen Púst' und Jurko); 6 - Burgwall bei Moravany; 7 - Kostolec bei Ducové; I. - durch Relikte verifizierte Trassen; II. - bislang nicht näher untersuchte mutmaßliche Trassenverläufe; III. - Zugangsverkehrsweg zum großmährischen Burgwall Bojná I; a-zz - Verkehrsbewegungsrelikte (Verzeichnis mit näheren Angaben siehe Anhang). Kartenvorlage: http://www.google.com/maps/, aufgerufen am 15. 6. 2014.

Pokud se týče hradiště Bojná I, na základě dosavadních poznatků bychom snad místo o tržním centru z doby velkomoravské mohli hovořit o významném útočištném hradišti skrytém v horách, s hlavním přístupem dobře hájitelnou zamokřenou Hradnou dolinou, v nadsázce snad o jakémsi „slovenském Machu-Picchu“. Ve střízlivější poloze zatím konstatujeme, že žádná z hlavních tras přes Považský Inovec hradištěm neprocházela, nicméně jeho poloha dávala dobré možnosti ty nejdůležitější komunikace kontrolovat. Vztah velkomoravského hradiště Boj-

9 Jde zejména o pozůstatky mohutného systému úvozů, který stoupá na hřbet Žihlavníku z místa rozdělení údolí na Hradnou dolinu a údolí Bojnianky (obr. 12:u). Zmínky K. Piety a A. Ruttkaye o komunikaci na hřbetu Žihlavníku v souvislosti s fortifikací Bojmá III (Pieta-Ruttkay 2006, 25; Pieta 2006, 180) tento systém úvozů nepostihují.

10 Podobná lineární fortifikace přetínající úvozy na hlavním komunikačním hřbetu východně od Pustého hradu u Zvolenu je datována do 7.-8. století (Pažinová-Beljak-Slámová-Beláček 2013, 164); patrně středověký val a př́kop přetíná horskou hřebenovou komunikaci procházejíci kolem hradu Lukova přes Hostýnské vrchy (Cendelín 2013,11). Za novověký pak lze pokládat val a př́kop (obrácený proti Čechám), kterým byl přet'at systém úvozů na Žitavské cestě v úrovni hradu Karlsfriedu.

11 Že K. Pieta lokalitu Bojná III chápe jako hradiště, dokládá mj. i formulací „hradiská I a III mali priechodný charakter“ (Pieta 2006, 183).

12 Dobře tradici vztahu zřizování mohyl a pravěkých pohřebišt' u starých cest dokumentuje vyjádření českého kronikáře Kosmy z 1 . čtvrtiny 12. století, podle kterého obyvatelé Čech po smrti bájné kněžny Kazi zbudovali mohylu při cestě, kterou se chodí do končin kraje Bechyňského (Kosmas I. 4, ed. Bretholz 1923, s. 10; k tomu Bolina-Klimek 2007). 
ná I k možným okolním dálkovým trasám byl podobný, jako mělo pravěké hradiště Bojná II. Za předpokladu, že všechny dálkové trasy v této části Považského Inovce, jak jejich průběh odvozujeme $\mathrm{z}$ doposud zjištěných reliktů, byly využívány v době osídlení hradiště Bojná I, leželo toto přibližně uprostřed mezi komunikací využívající hřbet Žihlavníku a trasou, která kolem Bieleného vrchu v sobě umožňovala spojit několik dopravních pohybů. Jednak pravděpodobně př́mo od Nitry přes lokalitu u kostela sv. Juraje (o ní Ruttkay 1975a; 2006, 193-197), ${ }^{13}$ jednak přes současnou osadu Bojná od přechodu pohoří Tribeč mezi dnešním městem Topol’čany a hradem Oponice. ${ }^{14}$

Trasa od pohoří Tribeč mohla využít k pokračování na sever i hřbetu nad levým břehem potoka Bojnianky, vrcholícím horou s pravěkým hradištěm Úhrad (kóta $684 \mathrm{~m}$ ). V blíže neurčené době a bez př́ímé návaznosti na předpolí hradiště Bojná II byla tato hřbetní komunikace přet’ata lineární fortifikací, kterou K. Pieta označuje jako Bojná IV (WGS-84: N48 37 11.6 E18 02 21.7). Výrazná soustava opuštěných úvozů na Žihlavníku velmi pravděpodobně také nezastupuje směr na Uherské Hradiště, nýbrž (při zachování pravidla přímé trasy) na Trenčínsko a do severněji položeného Pováží. Mimořádná intenzita opuštěných úvozů na Žihlavníku naznačuje používání trasy do nedávné minulosti, což snad koresponduje s germanismem „Vartovka“ v jedné části hřbetu. Výchozími body, které pro 9. a 10. století mohly určovat dopravní pohyb v prostoru kolem hradiska Bojná I, se tedy podle doposud zjištěných reliktů v terénu jeví Uherskohradišt'sko a Trenčínsko na straně jedné a Nitra s prostorem kolem ohybu Dunaje na straně druhé. Jak intenzivní byl pohyb na těchto komunikacích, je zatím nezjistitelné.

Výzkum starých dopravních tras provedený v okolí Bojné autory tohoto příspěvku je však nutné považovat za předběžný, celá oblast volá po komplexním řešení především s využitím LIDARu, kterým by komunikační vztahy tohoto regionu získaly mnohem větší vypovídací schopnost. Ale už nyní, bez ohledu na další postup výzkumu je zřejmé, že všem pozůstatkům starých cest v okolí Bojné by se mělo dostat zvýšené pozornosti ze strany orgánů památkové péče. Hrozí zde velké nebezpečí jejich poškozování či úplný zánik při současném způsobu hospodářského využití lesů za pomoci těžké mechanizace. Mimořádná lokalita Bojná I se svými významnými archeologickými nálezy tak již dnes nezadržitelně přichází o nezastupitelnou složku svého poznání.

\section{PŘÍLOHA}

Soupis autory zjištěných reliktů dopravního pohybu na Považském Inovci (v systému značení použitém na obr. 8, 12, 13 a 14)

Vždy jsou uvedeny souřadnice GPS (u rozlehlejších reliktů jejich přibližný střed), zjednodušený popis a př́ípadný vztah k okolním lokalitám.

\section{a - N48 37 14.4 E17 52 25.2}

Komunikační žleb u přechodu Hubinského potoka pod skalou Kostolce u Ducového ca $1 \mathrm{~km}$ ZSZ od centra osady Hubina.

\section{b - N48 3708.0 E17 5320.9}

Torzo menšího komunikačního žlebu a zbytky dvou opuštěných úvozů na okraji záhumenicových parcel osady Hubina ca $300 \mathrm{~m}$ SV od středu osady; pravděpodobně větev směřující k poloze Kamenne vráta na hřebeni Povážského Inovce.

\footnotetext{
13 Dle dochovaných reliktů (viz obr. 12:k, p) usuzujeme, že ve starši fázi se trasa od Nitry kolem rotundy sv. Juraje dostávala na hlavní hřbet Inovce přes sedlo Marhátu.

14 Autorům jsou z této trasy zatím známy úvozy u Nitrianske Stredy a Čeladinců (WGS-84: N48 3102.5 E18 11 08.4 ; N48 30 23.2 E18 10 45.8). Při směru zhruba SZ-JV lze hypoteticky dálkovou trasu přes pohoři Tribeč prodloužit do prostoru k ohybu Dunaje, při pohybu dál do Karpatské kotliny výhodném z hlediska eliminace dvojího přecházení dunajského veletoku (srov. obr. 2).
} 


\section{bb - N48 3801.1 E17 5401.8}

Výrazný systém úvozů sestupující k úzkému sedlu nad jižním koncem osady Modrová; trasa pravděpodobně pokračovala nad Modrovou a přes Lúku na Hrádok.

\section{c - N48 37 35.6 E175742.6}

Soustava opuštěných úvozů, ca $0,5 \mathrm{~km} \mathrm{~S}$ od Kostolného vrchu vedle lesní asfaltové cesty Jelenie Jamy - Stará Lehota; důležitý doklad spojení na Trenčínsko.

\section{d - N48 37 18.9 E17 5724.7}

Opuštěný úvoz, ca $0,5 \mathrm{~km}$ ZJZ od Kostolného vrchu vedle zpevněné lesní cesty ke kótě Grnica $523 \mathrm{~m}$ n.m.; pozůstatek komunikace využívané jak ve směru od Lúky a Modrové, tak Ducového a Hubiny.

\section{e - N48 37 14.9 E17 57 36.0}

Krátký opuštěný úvoz v kamenitém svahu náhorní plošiny ca $350 \mathrm{~m}$ JZ od Kostolného vrchu těsně vedle lokality Kamenne vráta; úvoz umožňoval přístup na náhorní plošinu od severu.

\section{f - N48 3707.9 E17 5736.0}

Tř́i opuštěné úvozy ve svahu pod dnešní zpevněnou cestou ca 0,3 km J od polohy Kamenne vráta; prostřední úvoz končí malou plošinou představující snad relikt strážného, kontrolního či pomocného objektu.

\section{g - N48 3701.9 E17 5719.0}

Dva krátké mělké opuštěné úvozy $0,9 \mathrm{~km} \mathrm{JZ}$ od Kostolného vrchu, zpř́istupňující od jihu náhorní plošinu vyvýšenou asi $10 \mathrm{~m}$ nad okolní cesty.

\section{h - N48 36 56.9 E17 5736.0}

Opuštěný úvoz vedle asfaltové cesty Stará Lehota - Jelenie Jamy ca $0,9 \mathrm{~km} \mathrm{~S}$ od lokality Jelenie Jamy; doklad hřebenové trasy.

\section{i - N48 3641.9 E17 5747.0}

Velký opuštěný úvoz vedle asfaltové cesty Stará Lehota - Jelenie Jamy ca $0,5 \mathrm{~km} \mathrm{~S}$ od Jeleních Jam; doklad hřebenové trasy.

\section{j - N48 3621.9 E17 5804.6}

Menší soustava mělkých úvozů ve výběžku lesa vedle lesní cesty ca $350 \mathrm{~m}$ VJV od Jeleních Jam; doklad trasy obcházející Bielený vrch po severní straně.

\section{k - N48 36 11.5 E17 5757.5}

Několik větších úvozů na kraji lesa vedle cesty z lokality Jelenie Jamy do sedla Marhátu; významný doklad pokračování hřebenové trasy na Nitransko, jak kolem polohy Jurko, tak po hřbetu nad Lipovníkem.

\section{I - N48 3602.9 E17 5902.9}

Opuštěný úvoz do svahu Bieleného vrchu ca $0,5 \mathrm{~km} \mathrm{~V}$ od jeho vrcholu; může jít o pokračování trasy přicházející přes relikt „,m“, které nad současnou zpevněnou cestou zkracovalo po úbočí Bieleného vrchu spojení s Jeleními Jamami.

\section{m - N48 36 03.0 E17 5907.0}

Dva úvozy blízko sebe $0,6 \mathrm{~km}$ V od vrcholu Bieleného vrchu, odbočující ze zatáčky současné zpevněné lesní cesty směrem na východ. 


\section{n - N48 35 48.8 E17 5901.5}

Opuštěný úvoz odbočující ze současné zpevněné lesní cesty ca $650 \mathrm{~m}$ JV od vrcholu Bieleného vrchu.

\section{o - N48 35 43.6 E17 58 58.5}

Úvozová cesta provázená třemi až čtyřmi opuštěnými úvozy ca $800 \mathrm{~m}$ JV od vrcholu Bieleného vrchu; úvoz, jímž komunikace pokračovala nad současnou zpevněnou lesní cestou, se v jižním svahu Bieleného vrchu záhy vytrácí, v opačném směru se úvozy po asi $250 \mathrm{~m}$ spojují s pokračováním reliktu „,n“. Trasa pak dál pokračuje po hřbetu, který vybíhá z Bieleného vrchu k JV.

\section{p - N48 3514.0 E17 5755.0}

Soustava opuštěných úvozů různého stupně dochování ca $100 \mathrm{~m}$ severně rotundy sv. Juraje; důležitý doklad trasy z Nitranska kolem rotundy sv. Juraje přes sedlo Marhátu na Jelenie Jamy a dál na Trenčínsko.

\section{q-N48 34 38.5 E17 5717.6}

Rozlehlá soustava opuštěných úvozů, vedle lesní cesty ca 2 km SSZ od Nitrianské Blatnice; důležitý doklad trasy Nitra - Uherské Hradiště, která přes sedlo Gajda pokračovala k reliktu ,zz“.

\section{r - N48 33 35.9 E17 5758.4}

Komunikační žleb erodovaný do podoby strže, končící u severního okraje Nitrianské Blatnice; pokračování trasy od reliktu „q“.

\section{s - N48 33 41.9 E17 5839.0}

Dnes rozoraný hluboký úvoz ca $1 \mathrm{~km} \mathrm{SV}$ od centra Nitrianské Blatnice na jednom z výběžků Považského Inovce, dobře viditelný na ortofotomapě z doby před r. 2014; relikt je pravděpodobně pozůstatkem původní trasy od kostela sv. Juraje na Nitru, která míjela Nitranskou Blatnici.

\section{t - N48 36 20.6 E18 0301.3}

Opuštěné úvozy vedle asfaltové lesní cesty stoupající z údolí Bojnianky na hřeben Babica ca $3 \mathrm{~km} \mathrm{~S}$ od centra Bojné.

\section{u - N48 36 25.7 E18 0219.3}

Rozsáhlá soustava opuštěných úvozů stoupajících na hřbet Žihlavníku ca 4,3 km SSZ od centra Bojné.

\section{v - N48 36 42.0 E18 0147.1}

Opuštěný úvoz kolmý na horní konec reliktu „u“, který dokládá dopravní pohyb od mohyly na hřbetu Žihlavníku do bočního údolí; mylně by mohl být pokládán za př́ikop fortifikace.

\section{w - N48 36 34.0 E18 0059.1}

Menší opuštěný úvoz v údolí Hradné doliny vedle současné zpevněné lesní cesty.

\section{$\mathrm{x}$ - N48 36 45.3 E18 0006.4}

Opuštěné úvozy v př́istupovém prostoru k SV bráně hradiště Bojná I.

\section{y - N48 35 23.0 E18 0134.0}

Soustava výrazných opuštěných úvozů ca $2,6 \mathrm{~km} \mathrm{SZ} \mathrm{od} \mathrm{centra} \mathrm{Bojné.}$ 


\section{z - N48 36 31.1 E17 5337.0}

Velký úvoz vysekaný do skalního podloží - vedle současné zpevněné cesty -, kterým trasa od Ducového překonávala severní svah údolí Striebornice. V horní části je úvoz zavážen odpadem z přilehlé zahrádkářské kolonie.

\section{zz - N48 3610.8 E17 5422.8}

Výrazný systém úvozů stoupajících na hřbet, který nad údolím Striebornice vrcholí fortifikací Hradište. Pokračování úvozů i na hřbetu směrem k sedlu Gajda.

\section{Prameny a literatura}

BIALEKOVÁ, D., 1978: Výskum a rekonštrukcia fortifikácie na slovanskom hradisku v Pobedime - Grabung und Rekonstruktion der Fortifikation auf dem slawiachen Burgwall in Pobedim, SlArch XXVII, $149-171$.

- 1998: Zur Bautechnik des Befestigungsmauer des Burgwalls in Pobedim, Bez. Trenčín. In: Frühmittelalterlicher Burgenbau in Mittel- und Osteuropa (Henning, J.-Ruttkay, A., edd.), 383-390. Bonn.

BOLINA, P.-CENDELÍN, D., 2014: „Ausgangspunkte“ - zur Methode der Altstraßenforschung. In: Tradition - Umgelstaltung - Innovation. Transformationsprozesse im hohen Mittelalter. Praehistorica 31/2 (Gringmuth-Dallmer, E.-Klápště, J., edd.), 743-755. Praha.

- 2011: Úloha hradů Lukov a Brumov v systému komunikací východní Moravy - Die Rolle der Burgen Lukov und Brumov im Verkehrswegesystem Ostmährens, AH 36, 87-108.

- v tisku: Historický přechod pomezí Čech a Moravy u Litomyšle - Historical Crossing the Bohemian-Moravian border by Litomyšl, Historica Olomucensia. Supplementum II., 91-150.

BOLINA, P.-KLIMEK, T., 2007: Úsek dálkové komunikace na Kosmově hoře Osek (Poznatky z povrchového průzkumu zaniklých cest v trati „Humenská“ na katastrálním území Jíloviště, okr. Praha-západ) A leg of a trunk road on the Cosmas' Hill Osec (The surface research of former roads in the Humenská tract in the cadastre area of Jíloviště, dist. Prague-West), AR LIX, 103-115.

CDM VII: Codex diplomaticus et epistolaris Moraviae. Tomus VII. (1334-1349) (Chytil, J., ed.). Brünn 1858.

CENDELÍN, D., 1999: Staré komunikace. Nákladem autora. Vizovice.

- 1999a: Terénní průzkum zaniklé středověké komunikace na západním Brněnsku - Terrainforschung einer verschwundenen mittelalterlichen kommunikation in der westbrünner Gegend, VVM LI, 48-57.

- 2001: Od Habrů k Brodu. Pokus o řešení jednoho problému viatistiky. In: Sborník Havličcobrodské společnosti pro povznesení regionálně historického povědomí, č. 1, 46-79. Havlíčkův Brod.

- 2010: Přechody Bílých Karpat z Moravy do Pováží. Přesná lokalizace dopravních linií a moravské př́íhraniční fortifikace - Übergänge der Weißen Karpaten von Mähren in der Slowakei. Genaue Ortsbestimmung der Verkehrslinien und mährischen Fortifikationen, VVM LXII, 297-315.

- 2011: Kosmas k roku 1116: Interpretace historické události v reflexi krajiny Moravsko-slovenského pomezí - Cosmas about 1116: Interpretation of a historic event in the reflection of the landscape on the Moravian-Slovak border, HG 37, č. 1, 7-48.

-2013: Relikty dopravního pohybu v Hostýnských vrších a na Holešovsku - Relikt dopravního pohybu jako archeologický objekt, Archeologie Moravy a Slezska XIII, 5-18.

CENDELÍN, D.-BOLINA, P., 2012: Pokračování trasy Lukov-Brumov-Vršatec do oblasti slovenských banských měst. In: Výzkum historických cest v interdisciplinárním kontextu (Martínek, J.-Šmeral, J., edd.), 20-27. Brno.

ČIŽMÁ ̌̌, M., 2004: Encyklopedie hradišt' na Moravě a ve Slezsku. Praha.

DOHNAL, V., 1984: Povrchové sběry na hradištích kultury lužických popelnicových polí na Moravě, PV 1982, 29-30.

- 1988: Opevněná sídliště z doby popelnicových polí na Moravě, Studie muzea Kroměřížska '88. Kroměříž.

HANULIAK, M., 1998: Komunikácie Slovenska z 10.-13. storočia v kontexte trás vojenských akcí - Die Kommunikationen in der Slowakei im 10.-13. Jahrhundert im Zusammenhang mit den Trassen der militärischen Operationen, AH 23, 233-244.

HENNING, J.-RUTTKAY, M.-DAŇOVÁ, K., 2009: Výskum včasnostredovekého hradiska v Pobedime, AVANS 2007, 75-77, 291-293.

CHALOUPECKÝ, V., 1923: Staré Slovensko. Bratislava. 
JANŠÁK, Š., 1961: Česká cesta - najstarši spoj Slovenska s českými krajmi, Vlastivedný časopis 10, č. 1, 82-87.

KOSMAS: Cosmae Pragensis Chronica Bohemorum. Monumenta Germanie Historica. Scriptores rerum Germanicarum. Nova Series. Tomus II. (Bretholz, B., ed.). Berlin 1923.

KRAJČOVIČ, R., 1992: Vel'komoravská cesta z Nitry na Moravu vo svetle lexiky starej toponymie, Slavia. Časopis pro slovanskou filologii 4, 453-459.

KUBÜ, F.-ZAVŘEL, P., 2007-2009: Zlatá stezka 1-3. České Budějovice.

PAULÍK, J., 1962: Velaticko-baierdorfská mohyla v Očkove pri Pieštanoch, AR XIV, 327-328, 336-340, 369.

- 1962a: Das Velatice-Baierdorfer Hügelgrab in Očkov, SlArch X, 5-96.

- 1994: Velatická mohyla v Očkove (výsledky doplnkového výskumu), ZbSNM LXXXVIII - Archeológia 4, 17-24.

PAŽINOVÁ, N.-BELJAK, J.-SLÁMOVÁ, M.-BELÁČEK, B., 2013: Stredoveká cestná siet' v okolí zvolenského Pustého hradu. Analýza na základe antropogénnych reliéfnych foriem - Mittelalterliches Straßennetz in der Umgebung von Pustý hrad (Wüste Burg) von Zvolen. Analyse auf der Grundlage von anthropogenen Reliefformen, ŠZ 54, 153-170.

PIETA, K., 2006: Hradiská Bojná II a Bojná III. Významné sídlo z doby stahovania národov a opevnenia z 9. storočia - Burgwälle Bojná II und Bojná II. Herrensitz der Völkerwanderungszeit und Befestigungen aus dem 9. Jahrhundert. In: Bojná, Hospodárske a politické centrum Nitrianskeho kniežactva - Wirtschaftliches und politisches Zentrum Nitraer Fürstentums (Pieta, K.-Ruttkay, A.-Ruttkay, M., edd.), 173-190. Nitra.

PIETA, K.-RUTTKAY, A., 2006: Bojná - mocenské a christianizační centrum Nitranskeho kniežatstva Bojná - neues Macht- und Christianisierungszentrum des Fürstentums von Nitra. In: Bojná, Hospodárske a politické centrum Nitrianskeho kniežactva - Wirtschaftliches und politisches Zentrum Nitraer Fürstentums (Pieta, K.-Ruttkay, A.-Ruttkay, M., edd.), 21-69. Nitra.

RATKOŠ, P., 1978: Naše sídliskové útvary v latinskej terminológii 9.-12. storočia - Unsere Siedlungsformen in der lateinischen Terminologie des 9.-12. Jahrhunderts, AH 3, 247-254.

RUTTKAY, A., 1975: Ducové. Vel'komoravský velmožský dvorec a včasnostredoveké pohrebisko. Materiály III. medzinárodného kongresu slovanskej archeologie (Bratislava 7.-4. septembra 1975). Nitra.

- 1975a: Včasnostredoveká rotunda a zaniknutý sídliskový región při Nitranskej Blatnici, AVANS 1974, 94-96.

- 1989: Feudálne sídla a fortifikačné zariadenia na Slovensku spred polovice 13. storočia (problematika a novšie výskumy), ZbSNM LXXXIII - História 29, 57-103.

- 2005: Frühmittelalterliche gesellschaftliche Eliten im Gebiet der Slowakei und ihre Sitze. In: Die frühmittelalterliche Elite bei den völkern des östlichen Mitteleuropas (mit einem speziellen Blick auf die grossmährische Problematik). Archeologický ústav AV ČR (Kouřil, P., ed.), 230-243. Brno.

- 2006: Významné archeologické lokality z včasného středověku v oblasti Povážského Inovce - Bedeutende frühmittelalterliche Fundorte in der Region Považský Inovec. In: Bojná, Hospodárske a politické centrum Nitrianskeho kniežactva - Wirtschaftliches und politisches Zentrum Nitraer Fürstentums (Pieta, K.-Ruttkay, A.-Ruttkay, M., edd.), 191-201. Nitra.

- 2012: Archeologické výskumy v oblasti pohoria Považský Inovec a panstvo hradu Tematín - Archeological research in the region of Považský Inovec mountain range and the estate of Tematín Castle. In: Mezi raným a vrcholným středověkem. Pavlu Kouřilovi k šedesátým narozeninám přátelé, kolegové a žáci, 487-520. Brno.

SEDLÁČEK, A., 1924: Úryvky o pojmenování silnic a cest, ČSPSČ XXXII, 37-40.

SLIVKA, M., 1998: Rekonštrukcia cestnej siete na Slovensku (Súčasný stav bádania a jeho perspektívy) Rekonstruktion des Wegenetzes in dr Slowakei (Der gegenwärtige Stand der Forschung und seine Perspektiven), AH 23, 259-275.

ŠMILAUER, V., 1932: Vodopis starého Slovenska. Praha - Bratislava.

\section{Zusammenfassung}

\section{Die Bedeutung von Verkehrsbewegungsrelikten bei der Interpretation des Grossmährischen Burgwalls bei Bojná (Bezirk Topol'čany)}

Im Zusammenhang mit den historischen Straßenverkehrswegen in der Slowakei tritt mit den schriftlichen Quellen und den Geländerelikten meistens die sogenannte Böhmische Stra- 
ße in den Vordergrund, die über Trnava, die Kleinen Karpaten und das mährische Städtchen Hodonín das Zentrum des mittelalterlichen ungarischen Staates mit den böhmischen Ländern verbindet. Ob und inwieweit die Nutzung der Böhmischen Straße bereits in die Zeit Großmährens projiziert werden kann, ist nicht bekannt. Theoretisch könnte sie für die angenommene Verbindung zwischen dem südlicher gelegenen Nitra und Mikulčice (Bez. Göding) geeignet gewesen sein, kaum jedoch für die Verkehrsbewegungen von Nitra zu dem weiteren, nördlicher gelegenen großmährischen Zentrum, dessen Existenz durch archäologische Grabungen fast für das gesamte, unterhalb der heutigen Stadt Uherské Hradiště liegende Gebiet belegt ist. Überlegungen über einen Verkehrsweg mit einem solchen Verlauf wurden durch bedeutende, kürzlich auf dem großmährischen Burgwall bei Bojná gemachte Entdeckungen bekräftigt.

Die Trasse Nitra-Uherské Hradiště wurde anfänglich mehr oder weniger schematisch behandelt, genauere Erkenntnisse lieferten erst ihre auf der mährischen Seite der Weißen Karpaten erhalten gebliebenen Relikte. Deren Entdeckung ermöglichte es den Verfassern, ihren weiteren Verlauf auf slowakischer Seite durch die Siedlung Krajné und um die urzeitlichen Grabhügel in Očkov bis zu den bedeutenden, von den archäologischen Grabungen aus den siebziger - achtziger Jahren des 20. Jahrhunderts bekannten großmährischen Fundstellen Pobedim und Ducové zu beobachten. Ferner konnte dann bereits an die von K. Pieta und A. Ruttkay angenommene Trasse über den das letzte Hindernis zwischen dem Waagtal und Nitra darstellenden Gebirgszug Považský Inovec (Inowetz) angeknüpft werden.

Durch eigens im Gebirgszug Považský Inovec von den Verfassern durchgeführte Untersuchungen wurden eine Reihe interessanter, von Verkehrsbewegungen stammender Relikte entdeckt. Von ihnen entsprechen der direkten Verbindung zwischen Uherské Hradiště und Nitra am meisten die Überbleibsel einer Trasse, die von Ducové über den Übergang des Flusstales Striebornica zum Bergkamm aufstieg, an dessen Ausläufer oberhalb des Tales sich der kleine urzeitliche bis frühmittelalterliche Burgwall Hradište u Moravan befindet. Die Fortsetzung der Trasse von dem Bergsattel Gajda nach Nitrianska Blatnica wird durch bedeutende Relikte belegt, die im nördlich von dieser Ortschaft gelegenen Wald von ihr erhalten geblieben sind.

Weitere, sich östlich von Ducové (bei der Ortschaft Hubina) befindende Relikte deuten darauf hin, dass die Trasse aus der Region Uherské Hradiště auch eine Fortsetzung zur verkehrswegemäßig besonders wichtigen Fundstelle Kamenné Vráta auf dem Hauptkamm des Gebirgszugs Považský Inovec hatte. Diese archäologisch bislang nicht untersuchte Fundstelle ermöglichte es den aus dem Waagtal führenden Trassen (von Ducové, Hrádek und Lúka) um den Berg Bielený Vrch nicht nur in die Region Nitra, sondern vor allem weiter nach Südosten zum Donauknie unterhalb der Mündung des Flusses Ipel' (Eipel) zu führen, was der Raum war, der eine zweimalige Überquerung der Donau in Richtung Karpatenbecken überflüssig machte. Diese Hypothese wird etwa auch von den entdeckten Trassenrelikten an den Westhängen des Tribetzgebirges gestützt.

Durch die Fundstelle Kamenne Vráta führte auch die kürzeste Verbindungslinie zwischen der Region Trenčín und Nitra, deren Relikte sowohl an der Nordseite des Bergsattels Marhát, als auch in der Nähe der Fundstellen Púst' und Jurko an der frühmittelalterlichen St. Georg-Rotunde entdeckt wurden. Ihren Ausgangspunkt in der Region Trenčín hatten auch Trassen, deren Relikte sich auf dem Bergkamm Žihlavník und dem (in einem urzeitlichen Burgwall auf dem Berg Úhrad gipfelnden) Bergkamm Mladý Háj befanden. Nach dem Abstieg vom Gebirgszug Považský Inovec vereinigten sie sich in der Nähe der heutigen Gemeinde Bojná wahrscheinlich mit dem erwähnten, in Richtung Donauknie verlaufenden Verkehrsweg. Anhand von Geländeuntersuchungen auf den Bergkämmen Žihlavník und Mladý Háj wurde der Charakter der Befestigungsanlagen Bojná III und Boja IV präzisiert, die sich Burgwällen typologisch nicht zuordnen lassen. Sie zählen zur Gruppe der von anderen Orten her bekannten Befestigungsanlagen linearen Charakters, mit denen wichtige Verkehrskorridore in verschiedenen Zeiträumen quer gesperrt wurden. Im vorliegenden Fall also die verkehrswegemäßig wichtigen Bergkämme.

Dem bisherigen Kenntnisstand nach lässt sich schlussfolgern, dass der großmährische Burgwall Bojná I nicht direkt an einer der überregional bedeutenderen Verkehrslinien lag. Er hatte zwar zwei gegenüberliegende Tore, war also durchgängig, mehr Gewicht hatte jedoch nur 
die Verkehrsbewegung von Nordosten her, am Zugang zum Burgwall durch das Hradná-Tal. Wenn der Burgwall Bojná I an der Kontrolle einer der Ferntrassen durch den Gebirgszug Považský Inovec beteiligt war, konnte es sich im Hinblick auf seine Lage dabei nicht um die - ca. $3 \mathrm{~km}$ entfernte - Trasse Nitra-Uherské Hradiště gehandelt haben, die lediglich durch schwieriges Gebirgsterrain erreichbar gewesen war. Wahrscheinlicher ist der Bezug des Burgwalls zu den Verkehrslinien, zwischen denen er ungefähr in der Mitte lag, also zu den aus Mähren und dem breiteren Waagtal (von Ducové, Hrádek und Trenčín) an den Hängen des Bergs Bielý Vrch und des Bergkamms Žihlavník entlang führenden Trassen im Südwesten, bei denen wir annehmen, dass sie vor allem bis zum Donauknie weiterführten. Der Burgwall hat auch die aus der Region Trenčín direkt nach Nitra verlaufende Verkehrsbewegung kontrollieren können, für die sich vom Osthang des Bergs Bielý Vrch aus eine anknüpfende und parallel zum Fluss Nitra südlich vom Gebirgszug Považský Inovec gelegene Anhöhe zur Nutzung anbot.

Ing. Pavel Bolina, CSc., V úvoze 245/12, 15900 Praha 5, bolinapavel@gmail.com

Dušan Cendelín, J. Haly 442, 76312 Vizovice, cendoch@gmail.com 
